\title{
Barriers to the Development of Smart Cities in Indian Context
}

\author{
Nripendra P. Rana ${ }^{1} \cdot$ Sunil Luthra ${ }^{2} \cdot$ Sachin Kumar Mangla ${ }^{3} \cdot$ Rubina $_{\text {Islam }}{ }^{4} \cdot$ Sian Roderick $^{5} \cdot$ Yogesh K. Dwivedi $^{1}$
}

Published online: 30 July 2018

(C) The Author(s) 2018

\begin{abstract}
Smart city development is gaining considerable recognition in the systematic literature and international policies throughout the world. The study aims to identify the key barriers of smart cities from a review of existing literature and views of experts in this area. This work further makes an attempt on the prioritisation of barriers to recognise the most important barrier category and ranking of specific barriers within the categories to the development of smart cities in India. Through the existing literature, this work explored 31 barriers of smart cities development and divided them into six categories. This research work employed fuzzy Analytic Hierarchy Process (AHP) technique to prioritise the selected barriers. Findings reveal that 'Governance' is documented as the most significant category of barriers for smart city development followed by 'Economic; 'Technology'; 'Social'; 'Environmental' and 'Legal and Ethical'. In this work, authors also performed sensitivity analysis to validate the findings of study. This research is useful to the government and policymakers for eradicating the potential interferences in smart city development initiatives in developing countries like India.
\end{abstract}

Keywords Smart cities $\cdot$ Barriers $\cdot$ Fuzzy AHP $\cdot$ Sensitivity analysis $\cdot$ Prioritisation $\cdot$ India

\section{Introduction}

Smart city development is gaining considerable recognition in the systematic literature and international policies in the last two decades (Albino et al. 2015; Koo et al. 2017; Mori and Christodoulou 2012). For this work, a smart city can be defined as a technologically advanced and modernised territory with a certain intellectual ability that deals with various social, technical, economic aspects of growth based on smart computing techniques to develop superior infrastructure constituents and services
(Bakıc1 et al. 2013; Cruz-Jesus et al. 2017; Washburn et al. 2010; Zygiaris 2013; Chatterjee and Kar 2018b).

As per the United Nations Population Fund, a large proportion of the population will shift to city regions by 2050 (UNFPA 2008). In India, urbanisation is growing rapidly and cities are likely to expand to 600 million by 2030 . Another study by Mckinsey (2018) reported that in the following 15 years, around 200 million people will transition from rural to urban areas in India. The change will be enormous, nearly equal to existing populations of France, Germany, and the United Kingdom combined. In this sense,
Yogesh K. Dwivedi

ykdwivedi@gmail.com

Nripendra P. Rana

nrananp@gmail.com

Sunil Luthra

sunilluthra1977@gmail.com

Sachin Kumar Mangla

sachin.kumar@plymouth.ac.uk

Rubina Islam

rubislam@gmail.com

Sian Roderick

s.roderick@swansea.ac.uk
1 Emerging Markets Research Centre (EMaRC), School of Management, Swansea University Bay Campus, Fabian Way, Swansea SA1 8EN, UK

2 Department of Mechanical Engineering, State Institute of Engineering and Technology, Nilokheri, Haryana 132117, India

3 Plymouth Business School, University of Plymouth, Plymouth PL4 8AA, UK

4 Salford Business School, The University of Salford, The Crescent, Salford M5 4WT, UK

5 School of Management, Swansea University Bay Campus, Swansea SA1 8EN, UK 
the Government of India (GoI) is committed to enhance the quality of life for citizens through its urban development agenda (Bloomberg Philanthropies 2017; Nair 2017). In light of this, GoI has listed 109 of India's most popular urban centres where the focus shifts from "highways to i-ways".

The urban population of India is growing at a lesser rate when compared to the global average ( $31.15 \%$ as per the 2011 census of India). The reason for this may be a lack of governmental supportive polices or challenges in managing the urban dynamics. On the other hand, countries such Chile, Mexico, Argentina, Brazil and China have responded by launching various timely initiatives to manage urbanization efficiently (Aijaz 2016). For example, Santiago de Chile has shown advancements on becoming smarter (Fast Company 2013). Similarly, the Chinese city Xinxiang pursued a joint programme with IBM to improve its transportation network and community safety (China Daily 2013). In citizens' quality of life index, countries such as Denmark, Switzerland and Australia are out performing Asian countries including India. For improving the quality of life, policymakers conducted an initiative of smart city development in India (OCED 2015; The Indian Express 2016). However, cities in developing countries like India are extremely different to design and implement.

Cities generate new kinds of physical problems such as scarcity of resources, air pollution, difficulty in waste management, traffic congestions, and inadequate, deteriorating and aging infrastructures etc. (Chourabi et al. 2012). Another set of challenges arise from the massive levels of digitization and generation of data (Chauhan et al. 2016). In recent years, a sequence of challenges in the cities' economies and needs has arisen, administering the promotion of the smart city idea. In addition, the literature also lacks a clear understanding of strategic planning for smart city projects (Angelidou 2015). There is a clear literature gap pertaining to the smart city agenda, including its theoretical development and evaluation of related challenges that facilitate implementation in a country context (Yigitcanlar 2015). Therefore, key barriers to the smart cities' development need to be identified and evaluated.

To help policymakers, in this work, the key barriers to the smart cities' development are identified from an evaluation of the literature and experts' feedback. Different experts might have diverse opinions regarding the barriers to the smart cities' development in India. Therefore, the experts on smart cities with regard to academia, industry and public-sector organisations were included to provide their views on the various barriers that may influence the way in which smart cities develop. Specifically, this research sets the following objectives: [i] Identification of relevant barriers of smart cities development in India, [ii] Prioritisation of barriers to recognise the most important barriers of smart cities development in India. The selection of barriers was made through literature and inputs received from experts. Prioritizing the barriers is a decision problem involving various criteria and sub-criteria. Various difficulties supplement the prioritization of barriers due to human involvement and indistinctness in data (Mangla et al. 2017). To remove the essential imprecision and ambiguity, this work uses the fuzzy set theory (Zadeh 1965). In this work, authors selected the fuzzy AHP (Analytic Hierarchy Approach) due to this technique's ability to determine the importance of the identified barriers under fuzzy surroundings (Govindan et al. 2015). The fuzzy AHP permits mixing fuzzy set theory with the AHP technique to capture the human bias in judgements when developing pairwise comparisons between barriers.

The remaining sections of the paper are structured as follows: Section 2 presents the related literature on smart cities and highlights the barriers of smart cities development. Section 3 discusses the solution methodology along with the research framework. Section 4 illustrates the data analysis and results. Section 5 presents the sensitivity analysis to examine the priority rank stability. Section 6 discusses the results and presents the theoretical contributions and implications for practice. Finally, Section 8 provides conclusions, limitations and directions of future research.

\section{Literature Review}

This section illustrates the literature linked to smart cities, and identifies the barriers related to smart cities development.

\subsection{Smart Cities Development}

The concept of smart city was first addressed in 1990s with an aim to centre the implications of information communication technology for superior infrastructures and upgradations in networks. The widespread use of information technologies also enables cities to empower the advancement of indispensable services for safety, health, governance and delivery (Hernández-Muñoz et al. 2011; Pereira et al. 2017). For assisting policymakers on smart city network design, the California Institute for Smart Communities explored ways of transforming a city into smart city along with the extent of utilisation of information technologies in smart city context (Alawadhi et al. 2012; Albino et al. 2015). As a highly significant and extremely sensible initiative, the European Commission started plans on smart cities in 2010 that underpin four dimensions for the cities including construction, heating and cooling systems, power and transportation. The objective related to transportation, for example, is to build an intelligent public conveyance and traffic management system that avoids congestion, helps reduce fuel consumption and supports safety measures (Djahel et al. 2013).

The latest GSMA report also recommends that transportation, such as intelligent transportation and traffic information 
systems, play important role in smart cities projects (Lee et al. 2014). Digital services also play a critical role in facilitating information and services access to the residents of smart cities (Chatterjee et al. 2018; Chatterjee and Kar 2018a). The European Commission has also endorsed "the smart city" calls to improve energy efficiency and green mobility for the community (Lazaroiu and Roscia 2012). Lee et al. (2013) suggested six key dimensions for the concept of smart city, in terms of economy, mobility, environment, people, living and governance. As of 2012, there were approximately 143 smart cities projects, out of which 35 projects in North America and 47 projects in Europe were seeking to adopt smart technologies in managing urban issues. These included - traffic congestions, energy requirements, higher resources etc. (Lee and Lee 2014). According to a pan-European research project - Intel Cities (2009), effective governance is key to smart city development (Paskaleva 2011). A review of diverse definitions and practices of smart cities across the world also indicates that most of these territories include widespread use of mobile infrastructure and services (Lee et al. 2014). In respect of an increasing urban population and improved service quality in India, researchers and policymakers should acquire a greater/a more informed understanding on smart city development and its relevant barriers.

\subsection{Barriers of Smart Cities Development}

Based on previous studies, this work listed 31 key barriers to smart city development.. Furthermore, in consultation with experts, this work then categorised the barriers into six key categories; details of data collection is provided in Section 4. The various categories and associated barriers are presented in Table 1.

\section{Research Methodology}

This work used fuzzy AHP as the research method. This approach allows factors/variables/phenomena to be weighted in terms of importance, in this case smart cities and their related barriers as well as the categories of barriers. First introduced in 1980 by Thomas L Saaty, AHP is a decision-making tool, which assists in developing a hierarchical structure of variables (Saaty 1980; Luthra et al. 2013; Luthra et al. 2016b). AHP/Fuzzy AHP is arguably superior to other decision analysis methods such as fuzzy TOPSIS/TOPSIS, fuzzy ANP/ ANP, and ELECTRE and due to their limited acceptability and complexity (Harputlugil et al. 2011; Mangla et al. 2017). AHP is accessible to use and produces robust results for managers. AHP highlights the alternative, which best accords to achieve the defined goal and understanding of the problem. A human presence can lead to subjectivity in the analysis, however, the application of AHP limits such biases
(Mangla et al. 2015). AHP provides the numerical priorities for each variable to attain the goal (Ordoobadi 2010). However, AHP has its own limitations, described as (Ishizaka and Labib 2009; Mangla et al. 2016):

i. Problem of rank reversal or changes in priority due to any changes in factors or alternatives

ii. The hypothesis of factors independence

iii. Human bias and subjectivity in their judgments in forming pair-wise comparisons

iv. Consensus measure, if context is same and a group of experts has divergent priorities

To deal with above problems, AHP techniques can be extended to modified AHP - Bayesian approach, Fuzzy AHP, and Grey AHP (Govindan et al. 2017; Kar 2015; Sahoo et al. 2016). Amonst these, fuzzy AHP is preferential, due to its simplicity and higher consistency (Junior et al. 2014; Prakash and Barua 2015). The Fuzzy AHP technique also allows (i) analysing the behaviour of complex system in decision-making; (ii) evaluating the human judgment by determining the relative importance of system variables. Therefore, this research proposes to use a fuzzy based AHP approach for prioritizing the barriers in smart city development in India. The flow map for the fuzzy based AHP technique is shown in Fig. 1, and the steps involved are explained as follows:

The fuzzy AHP involved several steps (Chan et al., 2008) as follows: Step 1: Formulating and defining the aim of research work: The aim of work to prioritize the barriers in smart cities development is defined. Step 2: Applying the fuzzy concepts: In a decision-making problem generally involves human assessments consist of qualitative judgments. Thereby, the fuzzy concepts are preferred (Dubois and Prade 1979; Zadeh 1965). The triangular fuzzy number (TFN) is used in this work. Step 3: Constructing a hierarchical structure: In respect to the aim of this work, a hierarchical structural keeping the experts' view into account is formed. Step 4: Developing a fuzzy pair wise assessment matrix: The pair wise assessment matrix for the barriers are formed. Prior to this, a nine-point scale of relative importance based on TFNs is designed (Table 2). Experts generally provide their feedback in terms of linguistic statements thus fuzzy scores were used to transform their linguistic inputs into numbers.

In order to develop a positive fuzzy comparison matrix (M), the average of the pair wise comparisons from expert panel is computed, which is given as $\mathrm{M}=\left[\mathrm{m}_{\mathrm{uv}}\right]_{\mathrm{n} \times \mathrm{m}}$.

Where, $\mathrm{m}_{\mathrm{xy}}$ shows the fuzzy entries in the developed fuzzy positive matrix, i.e., $\left(\mathrm{i}_{\mathrm{uv}}, \mathrm{j}_{\mathrm{uv}}, \mathrm{k}_{\mathrm{uv}}\right)$. Further, positive fuzzy numbers should also satisfy the properties, given as below:

$$
\mathrm{i}_{\mathrm{uv}}=\frac{1}{\mathrm{i}_{\mathrm{uv}}}, \mathrm{j}_{\mathrm{uv}}=\frac{1}{\mathrm{i}_{\mathrm{uv}}}, \mathrm{k}_{\mathrm{uv}}=\frac{1}{\mathrm{i}_{\mathrm{uv}}} \text {, where, } \mathrm{u} \text { and } \mathrm{v}=1,2
$$
................. i.e., no. of criteria. 
Table 1 The various categories and associated key barriers to smart cities development

\begin{tabular}{|c|c|c|c|c|}
\hline Category & S. No. & Key Barriers & Description & Reference \\
\hline \multirow[t]{6}{*}{ Governance (GOV) } & 1 & $\begin{array}{l}\text { Lack of cooperation and } \\
\text { coordination between city's } \\
\text { operational networks } \\
\text { (GOV1) }\end{array}$ & $\begin{array}{l}\text { Lack of ties between operational } \\
\text { nodes in the smart cities } \\
\text { implementation }\end{array}$ & $\begin{array}{l}\text { Elmangoush et al. (2013); } \\
\text { Kogan and Lee (2014); } \\
\text { Tachizawa et al. (2015) }\end{array}$ \\
\hline & 2 & $\begin{array}{l}\text { Unclear IT management } \\
\text { vision (GOV2) }\end{array}$ & $\begin{array}{l}\text { The lack of vision on how IT } \\
\text { management can be effectively } \\
\text { imposed to the development of } \\
\text { the smart cities }\end{array}$ & Chourabi et al. (2012) \\
\hline & 3 & Political instability (GOV3) & $\begin{array}{l}\text { Smart cities will not become a reality } \\
\text { until there is a political stability }\end{array}$ & $\begin{array}{l}\text { Kogan and Lee (2014); Letaifa } \\
\text { (2015) }\end{array}$ \\
\hline & 4 & $\begin{array}{l}\text { Lack of trust between governed } \\
\text { and government (GOV4) }\end{array}$ & $\begin{array}{l}\text { Lack of trust between government } \\
\text { and people can impede smart } \\
\text { cities development }\end{array}$ & $\begin{array}{l}\text { Balta-Ozkan et al. (2013); } \\
\text { Monzon (2015) }\end{array}$ \\
\hline & 5 & $\begin{array}{l}\text { Poor private-public } \\
\text { participation (GOV5) }\end{array}$ & $\begin{array}{l}\text { The poor private-public interaction } \\
\text { can negative impact smart cities } \\
\text { development projects }\end{array}$ & $\begin{array}{l}\text { Koppenjan and Enserink } \\
\text { (2009); Lee et al. (2014) }\end{array}$ \\
\hline & 6 & $\begin{array}{l}\text { Lack of developing a common } \\
\text { information system model }\end{array}$ & $\begin{array}{l}\text { Lack of a common IS model to } \\
\text { ensure end-to-end visibility }\end{array}$ & $\begin{array}{l}\text { Ballon et al. (2011); Naphade } \\
\text { et al. (2011) }\end{array}$ \\
\hline
\end{tabular}

Economic (ECO) $\quad 7 \quad$ High IT infrastructure and intelligence deficit (ECO1)

8

Lack of competitiveness (ECO2)

9

Cost of IT training and skills development (ECO3)

Global economy volatility (ECO4)

11 Higher operational and maintenance cost (ECO5)

Social (SOC)

Lack of involvement of citizens (SOC1)

Low awareness level of community (SOC2)

14 Geographical diversification problems (SOC3)

15 Degree of inequality (SOC4) while managing smart infrastructure and services.

Lack of IT infrastructure (e.g. solar based electrical systems, cloud computing) and capabilities of artificial intelligence (e.g. intelligent transport system, smart communities, e-health, smart grids, smart energy solutions etc.)

Lack of competitiveness among local firms to deal with the challenges emerged in the development of the smart cities.

High cost of IT training and skills development programme to the IT professionals is a barrier to the smart cities development

Increasing volatility and uncertainty in the global economy could be a major concern for the smart cities development

High cost of IT, professionals and consultancies, installation, operation and maintenance and training are concerns for the smart cities development

Lack of citizens' participation in realising how exactly the smart cities could possibly look like in their experience is reflected. The citizens should be encouraged to submit and evaluate ideas for innovation in smart city design.

Public lacks in understanding the idea of smart city, and its implications on their quality of life

Unbalanced geographical development can hamper the smart cities development

High degree of inequality in citizens' education, income, skills etc. can impede the smart cities development
Monzon (2015)

Monzon (2015)

Chourabi et al. (2012)

Ferrara (2015)

Chourabi et al. (2012)

Komninos et al. (2013); Kogan and Lee (2014); IET (2017); Schuurman et al. (2012)

IET (2017); Kogan and Lee (2014)

Monzon (2015)

Glaeser et al. (2009); Monzon (2015) 
Table 1 (continued)

\begin{tabular}{|c|c|c|c|c|}
\hline Category & S. No. & Key Barriers & Description & Reference \\
\hline \multirow[t]{6}{*}{ Technology (TECH) } & 16 & $\begin{array}{l}\text { Lacking technological } \\
\text { knowledge among } \\
\text { the planners (TECH1) }\end{array}$ & $\begin{array}{l}\text { The planners and policymakers of } \\
\text { smart cities development lack } \\
\text { enabling or transformative } \\
\text { technological knowledge that } \\
\text { may be needed for smart cities } \\
\text { development }\end{array}$ & Scuotto et al. (2016) \\
\hline & 17 & $\begin{array}{l}\text { Lack of access to technology } \\
\text { (TECH2) }\end{array}$ & $\begin{array}{l}\text { Lack of access to modern digital } \\
\text { technology to majority of } \\
\text { citizens can be a barrier toward } \\
\text { smart cities development }\end{array}$ & $\begin{array}{l}\text { Chourabi et al. (2012); } \\
\text { Monzon (2015) }\end{array}$ \\
\hline & 18 & $\begin{array}{l}\text { Privacy and security issues } \\
\text { (TECH3) }\end{array}$ & $\begin{array}{l}\text { Issues related to privacy and } \\
\text { security (e.g. threats from } \\
\text { hackers and viruses, low privacy, } \\
\text { high costs etc.) tend to be a } \\
\text { major concern for smart cities } \\
\text { development }\end{array}$ & $\begin{array}{l}\text { Balta-Ozkan et al. (2013); } \\
\text { Chourabi et al. (2012); } \\
\text { Elmaghraby and Losavio } \\
\text { (2014) }\end{array}$ \\
\hline & 19 & $\begin{array}{l}\text { System failures issues } \\
\text { (TECH4) }\end{array}$ & $\begin{array}{l}\text { This failure could be anything from } \\
\text { city-wide public Wi-Fi systems } \\
\text { to the provisions of smart water } \\
\text { meter in individual homes }\end{array}$ & Datta (2016) \\
\hline & 20 & $\begin{array}{l}\text { Integration and convergence } \\
\text { issues across IT networks } \\
\text { (TECH5) }\end{array}$ & $\begin{array}{l}\text { Lack of integration of disparate } \\
\text { technology and convergence of } \\
\text { heterogeneous networks (e.g. } \\
\text { Bluetooth, WLAN, } \\
\text { heterogeneous cellular networks } \\
\text { such as } 3 \mathrm{G}, 4 \mathrm{G}, 5 \mathrm{G} \text { etc.) could } \\
\text { be potential issues toward smart } \\
\text { cities development }\end{array}$ & $\begin{array}{l}\text { Chourabi et al. (2012); Kogan } \\
\text { and Lee (2014); Lee et al. } \\
\text { (2014) }\end{array}$ \\
\hline & 21 & $\begin{array}{l}\text { Poor data availability and } \\
\text { scalability (TECH6) }\end{array}$ & $\begin{array}{l}\text { There is a lack of specific data and } \\
\text { corresponding scalable methods } \\
\text { in smart city development agenda }\end{array}$ & Gluhak (2017) \\
\hline \multirow[t]{5}{*}{ Environmental (ENV) } & 22 & $\begin{array}{l}\text { Lacking ecological view in } \\
\text { behaviour (ENV1) }\end{array}$ & $\begin{array}{l}\text { Lack of ecological view in } \\
\text { pro-environmental behaviour } \\
\text { toward consuming energy }\end{array}$ & Kogan and Lee (2014) \\
\hline & 23 & $\begin{array}{l}\text { Growing population problems } \\
\text { (ENV2) }\end{array}$ & $\begin{array}{l}\text { Rapidly increasing population } \\
\text { could be a concern for the smart } \\
\text { cities development }\end{array}$ & Neirotti et al. (2014) \\
\hline & 24 & $\begin{array}{l}\text { Lack of sustainability } \\
\text { considerations (ENV3) }\end{array}$ & $\begin{array}{l}\text { Lack of more sustainable and more } \\
\text { aware city (e.g. direct traffic, } \\
\text { notify residents about available } \\
\text { parking, reduce gas emissions } \\
\text { etc.) means lack of better living } \\
\text { conditions and experiences for all }\end{array}$ & $\begin{array}{l}\text { Neirotti et al. (2014); Yoon } \\
\text { (2015) }\end{array}$ \\
\hline & 25 & $\begin{array}{l}\text { Carbon emissions effect } \\
\text { (ENV4) }\end{array}$ & $\begin{array}{l}\text { Inability of shifting cities toward } \\
\text { low carbon trajectory and } \\
\text { emission reduction actions }\end{array}$ & Mandal (2016) \\
\hline & 26 & $\begin{array}{l}\text { Degradation of resources } \\
\text { (ENV5) }\end{array}$ & $\begin{array}{l}\text { Shortage of resources like supply } \\
\text { of fresh water and food }\end{array}$ & Monzon (2015) \\
\hline \multirow[t]{3}{*}{ Legal and Ethical (L\&E) } & 27 & Cultural issues (L\&E1) & $\begin{array}{l}\text { Lack of inflow of creative and } \\
\text { sharing culture of the people } \\
\text { living together in smart cities }\end{array}$ & $\begin{array}{l}\text { Nam and Pardo (2011); } \\
\text { Chourabi et al. (2012); } \\
\text { Monzon (2015) }\end{array}$ \\
\hline & 28 & $\begin{array}{l}\text { Lacking standardization } \\
\text { (L\&E2) }\end{array}$ & $\begin{array}{l}\text { Lack of standardization across } \\
\text { indicators (e.g. smart } \\
\text { technologies, security, privacy, } \\
\text { quality of life, environmental } \\
\text { sustainability, physical } \\
\text { infrastructure, mobile networks } \\
\text { etc.) has emerged as one of the } \\
\text { crucial hindrance in smart city } \\
\text { context }\end{array}$ & $\begin{array}{l}\text { Bhattacharya et al. (2015); } \\
\text { Kogan and Lee (2014) }\end{array}$ \\
\hline & 29 & $\begin{array}{l}\text { Issues of openness of data } \\
\text { (L\&E3) }\end{array}$ & $\begin{array}{l}\text { Open data and its accessibility is an } \\
\text { issue in the smart cities, which }\end{array}$ & Kogan and Lee (2014) \\
\hline
\end{tabular}


Table 1 (continued)

\begin{tabular}{|c|c|c|c|c|}
\hline \multirow[t]{4}{*}{ Category } & S. No. & Key Barriers & Description & Reference \\
\hline & & & $\begin{array}{l}\text { can impede the way the smart } \\
\text { city services can be delivered to } \\
\text { cities' residents and businesses }\end{array}$ & \\
\hline & 30 & $\begin{array}{l}\text { Lack of transparency and liability } \\
\quad(\mathrm{L} \& \mathrm{E} 4)\end{array}$ & $\begin{array}{l}\text { Inhibited transparency and unclear } \\
\text { lines of political accountability } \\
\text { in delivering most services could } \\
\text { be a concern for smart cities } \\
\text { development. The lack of } \\
\text { transparency risks isolating the } \\
\text { very people smart cities } \\
\text { technology is supposed to serve }\end{array}$ & Nam and Pardo (2011) \\
\hline & 31 & $\begin{array}{l}\text { Lack of regulatory norms, } \\
\text { policies and directions } \\
\text { (L\&E5) }\end{array}$ & $\begin{array}{l}\text { Lack of appropriate laws, } \\
\text { regulations or directives for the } \\
\text { smart cities development }\end{array}$ & Chourabi et al. (2012) \\
\hline
\end{tabular}

Step 5: Devising barriers significance weights: The fuzzy assessment matrix is further evaluated using Chang's Extent Analysis method (Chang 1996; Luthra et al. 2015; Mangla et al. 2017). This helps in determining the significance weights of barriers. The detail for Chang's Extent Analysis method is given in Appendix 1.

A conceptual framework for analysing the identified inhibitors relevant to smart city development is proposed (see Fig. 2). The framework is developed by following the guidelines of Platts and Gregory (1990) and given as below:

i. Involved processes are strictly relevant to existing framework. Analysis of the literature, selection of barriers and research methodology applicability all are associated with the research aim.

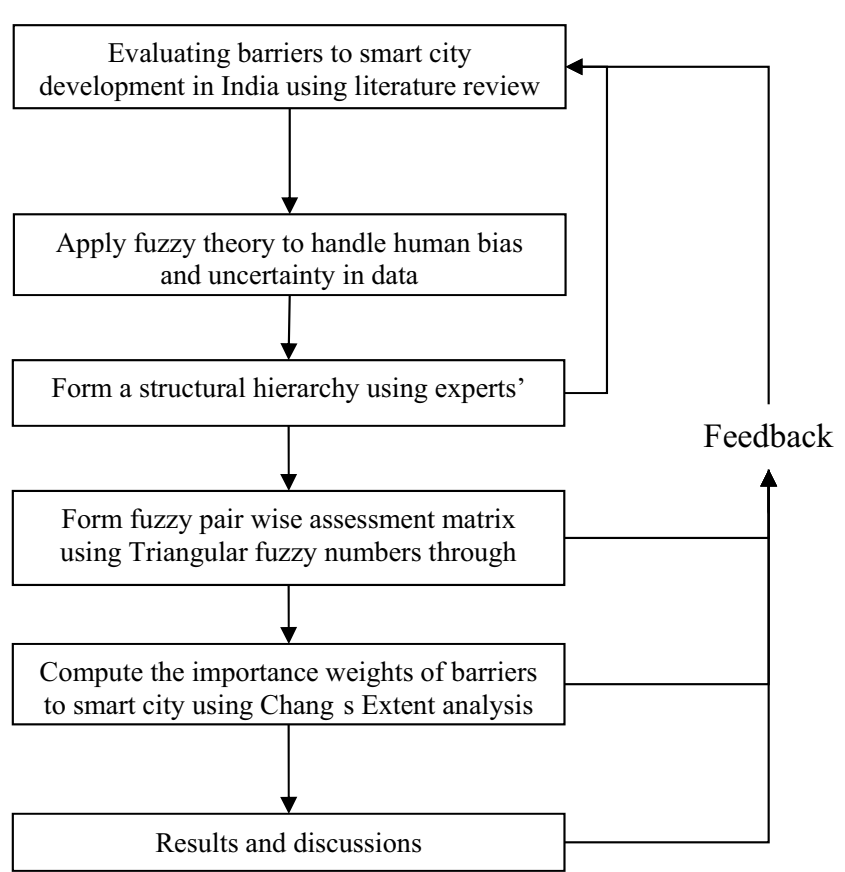

Fig. 1 Fuzzy AHP flow diagram for this work ii. Involved processes of the framework are well supported by literature and thereafter verified through experts' feedback. The conceptual research framework consists of two phases. In Phase 1, this work seeks to select the most suitable barriers to smart city development in Indian context. The selection of the most suitable barriers is grounded on literature survey and feedback received from the experts'. In Phase 2, we seek to explore the relative importance of the listed most suitable barriers and the categories of barriers. To achieve this, fuzzy based AHP approach is used (see Section 5.3). However, the suggested framework is not tested empirically at this stage of this work.

The conceptual framework depicts a real-life illustration of the issues of smart city development in India perspective as presented in Section 4. However, questionnaire and data collection is demonstrated in the next sub-section.

\subsection{Questionnaire Development and Data Collection}

A total of 31 barriers attributed to six categories to smart cities development were identified from the extensive literature review. This work has been conducted in an Indian case context (single case study type). The case study approach is significant to the theoretical development of the domain (smart city

Table 2 Fuzzy linguistic scale (Source: Mangla et al. 2015)

\begin{tabular}{ll}
\hline Uncertain judgment & Fuzzy score \\
\hline Almost equivalent & $1 / 2,1,2$ \\
Almost $x$ times more important & $\mathrm{x}-1, \mathrm{x}, \mathrm{x}+1$ \\
Almost $\mathrm{x}$ times less important & $1 / \mathrm{x}+1,1 / \mathrm{x}, 1 / \mathrm{x}-1$ \\
Between $\mathrm{y}$ and $\mathrm{z}$ times more important & $\mathrm{y},(\mathrm{y}+\mathrm{z}) / 2, \mathrm{z}$ \\
Between $\mathrm{y}$ and $\mathrm{z}$ times less important & $1 / \mathrm{z}, 2 /(\mathrm{y}+\mathrm{z}), 1 / \mathrm{y}$ \\
\hline
\end{tabular}

The values of $x$ range from $2,3 \ldots 9$, whereas the values of $y$ and $z$ can be $1,2 \ldots 9$ with $y<z$ 
Fig. 2 Proposed framework

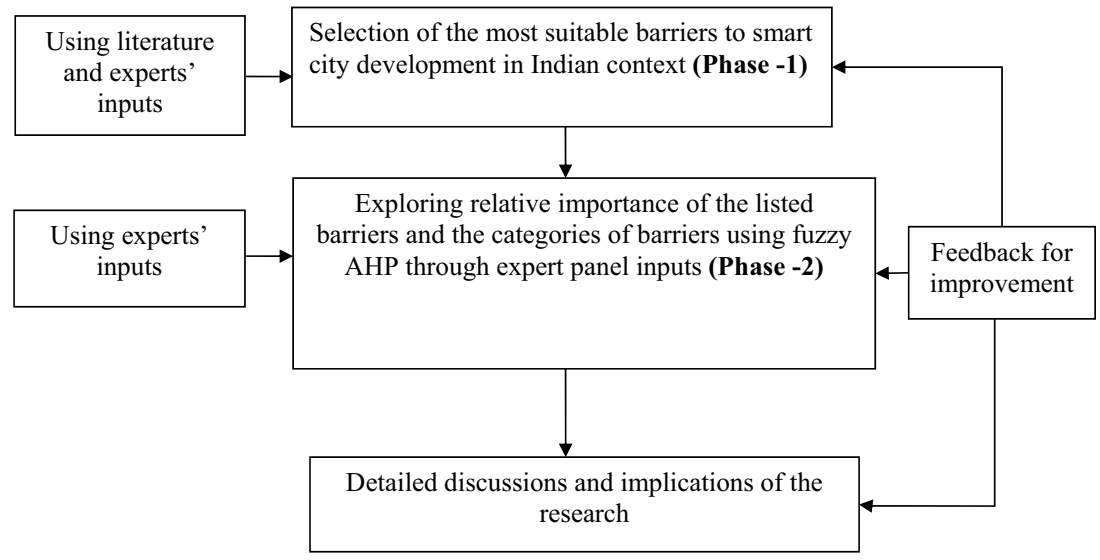

agenda). The case study research can also reveal the cognitive behaviour of a system, and thus underpins the empirical research in the domain (Voss et al. 2002). Due to the insufficiency in theory and expertise on smart city, this work prefers to discourse smart city development using expert's opinions (Mangla et al. 2015). Initially, twenty experts linked to smart cities project were contacted by phone, emails and direct visits to explain the purpose of the research. The selection of experts was dependent on the basis of researchers' convenience, cardinal consensus and personal contacts. Eight out of twenty experts felt they were able to participate in this research. This is considered as a satisfactory size for the present case based research (Lin 2013; Luthra et al. 2016a) provided that experts selected represent an intensive understanding of smart city development projects in Indian context. To examine the barriers to smart cities development in Indian context, we conducted a one-day workshop on "Smart City Design" on March 7, 2017 in New Delhi, India. The experts were highly skilled professionals from finance and operations, project management skills, ministry level professionals, environment management, and decision analysts.

Overall, this work can be applied to a limited context conducted with a comparable sample size ( 8 experts) but confirms a basis for further research that could be generalised to larger populations. For further clarity on the expert's background, the demographic summary of experts with various criteria is provided in the Table 3.

\section{Data Analysis and Results}

Fuzzy AHP is utilized to find the dominant barriers to smart city development in Indian context. Data analysis and related results have been provided. The proposed framework is applied to the research problem under study with other details as below:
Table 3 Experts' demographic information

\begin{tabular}{lll}
\hline Category & Classification & No. of experts \\
\hline Educational qualification & Master & 3 \\
& Ph.D. & 5 \\
Work experience & 5 to 10 Years & 1 \\
& 11 to 15 Years & 2 \\
Size of organization & Greater than 20 Years & 4 \\
& 51 to 250 Employees & 1 \\
& 251-500 Employees & 2 \\
Sector classification & 501-1000 employees & 1 \\
& $1001-5000$ employees & 2 \\
& Greater than 5001 employees & 1 \\
& Private Sector & 2 \\
& Public Sector & 2 \\
\hline
\end{tabular}




\subsection{Phase 1: Most Suitable Barriers Relevant to Smart City Development}

The author explored the literature using specific keywords including 'barriers' and 'smart cities development'; 'challenges and smart cities development'; 'problems/issues and smart cities development' in their various forms using the Scopus database and Google Scholar. Authors also searched specific grey literature, web content, government consultation documents, policy papers, to search for the barriers of smart cities development. A comprehensive review of keywords across various literature surveys fetched us 31 key barriers to smart cities development.

To validate these literature based barriers, a Delphi group session/consultation was conducted with the consent of experts. The experts were asked to rate the listed barriers in smart city adoption on 5 -point Likert scale $(1=$ not at all and $5=$ very significant) through a questionnaire shown in AppendixA. The mean scores of barriers and their standard deviations to smart cities development in the Indian context are also identified as given in Table 4.

The barriers with rating of 2 or mean value less than 2 were decided to be deleted. From Table 4, no barrier has obtained mean value less than 2 , so as no barrier was deleted from the list. The experts were also asked to make any modification in the list of barriers; however, all the experts were agreed on the 31 literature-based barriers. In this way, all the identified 31 barriers were validated.

In this phase, the previously identified thirty-one barriers were presented to experts for developing appropriate categories of barriers. The experts suggested evaluating 31 barriers to smart city development in the context of a developing economy like India through PESTEL analysis. However, the government has a vital role in initiating and executing smart city
Table 4 Mean score of barriers to smart city development

\begin{tabular}{|c|c|c|c|}
\hline SL & Barriers to smart cities development & Mean & $\mathrm{SD}$ \\
\hline 1 & Lack of cooperation and coordination between city's operational networks (GOV1) & 3.25 & 0.71 \\
\hline 2 & Unclear IT management vision (GOV2) & 3.88 & 0.83 \\
\hline 3 & Political instability (GOV3) & 3.38 & 1.06 \\
\hline 4 & Lack of trust between governed and government (GOV4) & 3.50 & 1.20 \\
\hline 5 & Poor private-public participation (GOV5) & 3.75 & 1.39 \\
\hline 6 & Lack of developing a common information system model (GOV6) & 3.13 & 1.13 \\
\hline 7 & High IT infrastructure and intelligence deficit (ECO1) & 3.38 & 1.30 \\
\hline 8 & Lack of competitiveness (ECO2) & 2.25 & 1.28 \\
\hline 9 & Cost of IT training and skills development (ECO3) & 2.63 & 1.06 \\
\hline 10 & Global economy volatility (ECO4) & 2.25 & 1.28 \\
\hline 11 & Higher operational and maintenance cost (ECO5) & 3.50 & 1.69 \\
\hline 12 & Lack of involvement of citizens (SOC1) & 3.50 & 1.20 \\
\hline 13 & Low awareness level of community (SOC2) & 3.88 & 1.36 \\
\hline 14 & Geographical diversification problems (SOC3) & 2.88 & 1.13 \\
\hline 15 & Degree of inequality (SOC4) & 3.38 & 0.92 \\
\hline 16 & Lacking technological knowledge among the planners (TECH1) & 3.75 & 0.71 \\
\hline 17 & Lack of access to technology (TECH2) & 3.25 & 1.04 \\
\hline 18 & Privacy and security issues (TECH3) & 3.25 & 1.04 \\
\hline 19 & System failures issues (TECH4) & 3.50 & 0.76 \\
\hline 20 & Integration and convergence issues across IT networks (TECH5) & 3.63 & 0.92 \\
\hline 21 & Poor data availability and scalability (TECH6) & 3.50 & 1.20 \\
\hline 22 & Lacking ecological view in behaviour (ENV1) & 2.63 & 0.92 \\
\hline 23 & Growing population problems (ENV2) & 3.00 & 1.07 \\
\hline 24 & Lack of sustainability considerations (ENV3) & 2.88 & 0.64 \\
\hline 25 & Carbon emissions effect (ENV4) & 2.63 & 0.92 \\
\hline 26 & Degradation of resources (ENV5) & 2.75 & 1.49 \\
\hline 27 & Cultural issues (L\&E1) & 2.63 & 1.19 \\
\hline 28 & Lacking standardization (L\&E2) & 3.13 & 0.99 \\
\hline 29 & Issues of openness of data (L\&E3) & 3.00 & 0.93 \\
\hline 30 & Lack of transparency and liability (L\&E4) & 3.50 & 1.07 \\
\hline 31 & Lack of regulatory norms, policies and directions (L\&E5) & 3.75 & 1.39 \\
\hline
\end{tabular}


projects in India. One of the experts suggested the inclusion of ethics along with legal aspects for PESTEL analysis. For this reason, the additional categories of governance and ethics were added to PESTEL analysis. In this sense, 31 most relevant barriers housed within 6 categories underwent PESTEL analysis in order to know the priorities when using the expert panel inputs.

\subsection{Phase 2: Prioritizing the Smart City Development Barriers by Means of Fuzzy AHP}

In this stage, the finalized smart city development barriers and their categories were evaluated to know their significance. Due to human involvement, this process of prioritizing the barriers might be biased, and thus, fuzzy AHP technique is used.

\subsubsection{Hierarchical Structure}

A hierarchical structure for this research is developed using expert inputs. The developed decision hierarchy contains of three distinct levels, given as, prioritizing the barriers to smart city development (at Level-1), six categories of barriers (at Level-2) and thirty-one smart city redevelopment related barriers (at Level-3) (see Fig. 3).

\subsubsection{Formation of the Fuzzy Pair Wise Assessment Matrix}

Pair wise assessments are formed for barriers by using experts' inputs by means of a scale (see Table 2). The professional in expert panel evaluated the pair wise rating by using linguistic statements and expressions. Expert opinion (majority of expert's opinion) (Mangla et al. 2015) helped to finalize the pairwise comparison matrix of barriers. We also conducted a group session to locate any major deviation in the pairwise comparisons and develop agreement among expert's opinions. This iterative process helped to build the rigor in the selection process framework. In addition, use of fuzzy set theory and TFNs helps in managing the consistency for matrices (pairwise comparisons). Fuzzy set theory allows experts to provide their inputs using an interval as being illustrated in Table 4 above. In this sense, pairwise comparison of attributes is shown in Table 5. In this way, fuzzy pair wise assessment matrix for categories of barriers is finalized (see Table 5).

\subsubsection{Barrier Preference Weights and their Relative Importance}

The preference weights were devised in correspondance to each category and their specific barriers using Chang's Extent Analysis method as mentioned in appendix A. The associated $\mathrm{S}_{\mathrm{i}}$ values can be computed, as follows

$$
\begin{aligned}
S_{1}= & (8.58,11.69,14.83) \\
& \times\left(\frac{1}{68.6482}, \frac{1}{50.0740}, \frac{1}{35.7970}\right) \\
= & (0.1250,0.2335,0.4143) \\
S_{2}= & (7.580,10.2333,13.00) \\
& \times\left(\frac{1}{68.6482}, \frac{1}{50.0740}, \frac{1}{35.7970}\right) \\
= & (0.1104,0.2044,0.3632)
\end{aligned}
$$

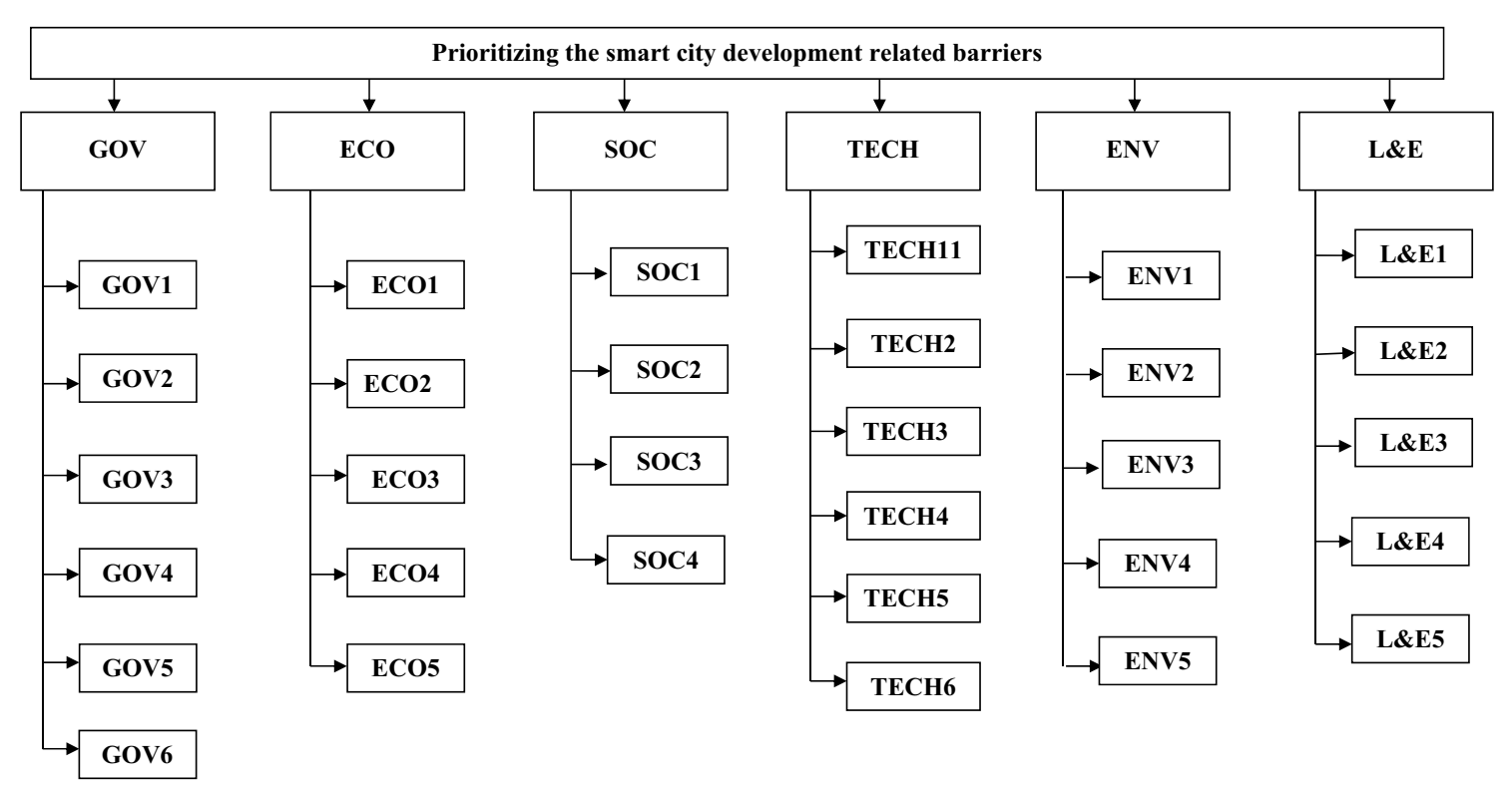

Fig. 3 The developed decision hierarchy of barriers to smart city development 
Table 5 Pair-wise judgment matrix for categories of barriers to smart city development

\begin{tabular}{|c|c|c|c|c|c|c|c|c|c|c|c|c|c|c|c|c|c|c|}
\hline \multirow{2}{*}{$\begin{array}{l}\text { Categories of barriers } \\
\text { GOV }\end{array}$} & \multicolumn{3}{|l|}{ GOV } & \multicolumn{3}{|l|}{ ECO } & \multicolumn{3}{|l|}{ SOC } & \multicolumn{3}{|c|}{$\mathrm{TECH}$} & \multicolumn{3}{|l|}{ ENV } & \multicolumn{3}{|l|}{ L\&E } \\
\hline & 1.00 & 1.00 & 1.00 & 2.00 & 3.00 & 4.00 & 0.25 & 0.29 & 0.33 & 0.33 & 0.40 & 0.50 & 2.00 & 3.00 & 4.00 & 3.00 & 4.00 & 5.00 \\
\hline ECO & 0.25 & 0.33 & 0.50 & 1.00 & 1.00 & 1.00 & 1.00 & 2.00 & 3.00 & 3.00 & 3.50 & 4.00 & 0.33 & 0.40 & 0.50 & 2.00 & 3.00 & 4.00 \\
\hline SOC & 3.03 & 3.45 & 4.00 & 0.33 & 0.50 & 1.00 & 1.00 & 1.00 & 1.00 & 0.33 & 0.50 & 1.00 & 0.33 & 0.50 & 1.00 & 1.00 & 2.00 & 3.00 \\
\hline TECH & 2.00 & 2.50 & 3.03 & 0.25 & 0.29 & 0.33 & 1.00 & 2.00 & 3.03 & 1.00 & 1.00 & 1.00 & 0.50 & 1.00 & 2.00 & 0.50 & 1.00 & 2.00 \\
\hline ENV & 0.25 & 0.33 & 0.50 & 2.00 & 2.50 & 3.03 & 1.00 & 2.00 & 3.03 & 0.50 & 1.00 & 2.00 & 1.00 & 1.00 & 1.00 & 0.33 & 0.50 & 1.00 \\
\hline L\&E & 0.20 & 0.25 & 0.33 & 0.25 & 0.33 & 0.50 & 0.33 & 0.50 & 1.00 & 0.50 & 1.00 & 2.00 & 1.00 & 2.00 & 3.03 & 1.00 & 1.00 & 1.00 \\
\hline
\end{tabular}

$$
\begin{aligned}
S_{3}= & (6.0236,7.9483,11.00) \\
& \times\left(\frac{1}{68.6482}, \frac{1}{50.0740}, \frac{1}{35.7970}\right) \\
= & (0.0877,0.1587,0.3073) \\
S_{4}= & (5.25,7.7857,11.3939) \\
& \times\left(\frac{1}{68.6482}, \frac{1}{50.0740}, \frac{1}{35.7970}\right) \\
= & (0.0765,0.1555,0.3183) \\
S_{5}= & (5.08,7.3333,10.5606) \\
& \times\left(\frac{1}{68.6482}, \frac{1}{50.0740}, \frac{1}{35.7970}\right) \\
= & (0.0740,0.14640 .2950) \\
S_{6}= & (3.2833,4.0833,6.8636) \\
& \times\left(\frac{1}{68.6482}, \frac{1}{50.0740}, \frac{1}{35.7970}\right) \\
= & (0.0478,0.0815,0.1917)
\end{aligned}
$$

The degree of possibility for two fuzzy numbers is given as,

$$
\begin{aligned}
V\left(S_{1} \geq S_{2}\right) & =\frac{(0.1104-0.4143)}{(0.2335-0.4143)-(0.2044-0.1104)} \\
& =1.0000 \\
V\left(S_{1} \geq S_{3}\right) & =1 \\
V\left(S_{1} \geq S_{4}\right) & =1 \\
V\left(S_{1} \geq S_{5}\right) & =1 \\
V\left(S_{1} \geq S_{6}\right) & =1
\end{aligned}
$$

Next, the minimum weight vectors for each fuzzy number are calculated:

$$
\begin{aligned}
z^{\prime}\left(C_{1}\right) & =\min \mathrm{V}\left(S_{1} \geq S_{2}, S_{3}, S_{4}, S_{5}, S_{6}\right)=\min (1,1,1,1,1) \\
& =1
\end{aligned}
$$

$z^{\prime}\left(C_{2}\right)=0.8890$

$z^{\prime}\left(C_{3}\right)=0.7310$

$z^{\prime}\left(C_{4}\right)=0.7410$

$z^{\prime}\left(C_{5}\right)=0.6920$

$z^{\prime}\left(C_{6}\right)=0.3040$

Next, the normalized values and their corresponding significance weights are computed. Thus, the weight vectors for the categories of barriers have been established and hence their relative importance are established (see Table 6).

'Governance (0.2295)' is recognised as the most important category of barriers for smart city development followed by 'Economic (0.2040)'; 'Technology (0.1701)'; 'Social (0.1678)'; 'Environmental (0.1588)' and 'Legal and Ethical (0.0698)' are shown in Table 5. In the next level, relative and global preference weights of specific barriers are determined (see Table 7). Based on this, the final ranks of barriers for smart city development have been made. Global ranking of barriers is summarized in Table 7.

Since the group of experts comes from divergent background, and the objective is to understand their prioritization of drivers of a larger context, the consensus was not computed in the prioritization since that would reduce the difference of priorities among the barriers.

Table 6 Rank of categories of barriers to smart city development

\begin{tabular}{lll}
\hline Categories of barriers & Preference weights & Ranking \\
\hline GOV & 0.2295 & 1 \\
ECO & 0.2040 & 2 \\
SOC & 0.1678 & 4 \\
TECH & 0.1701 & 3 \\
ENV & 0.1588 & 5 \\
L\&E & 0.0698 & 6 \\
\hline
\end{tabular}


Table 7 Final rank of specific barriers to smart city development

\begin{tabular}{|c|c|c|c|c|c|}
\hline $\begin{array}{l}\text { Category of } \\
\text { barriers }\end{array}$ & $\begin{array}{l}\text { Specific } \\
\text { barriers }\end{array}$ & $\begin{array}{l}\text { Relative preference } \\
\text { weights }\end{array}$ & $\begin{array}{l}\text { Relative } \\
\text { ranking }\end{array}$ & $\begin{array}{l}\text { Global preference } \\
\text { weights }\end{array}$ & $\begin{array}{l}\text { Global } \\
\text { ranking }\end{array}$ \\
\hline \multirow[t]{6}{*}{ GOV } & GOV1 & 0.1832 & 2 & 0.0420 & 6 \\
\hline & GOV2 & 0.1635 & 3 & 0.0375 & 8 \\
\hline & GOV3 & 0.2151 & 1 & 0.0494 & 4 \\
\hline & GOV4 & 0.1549 & 5 & 0.0355 & 12 \\
\hline & GOV5 & 0.1593 & 4 & 0.0366 & 9 \\
\hline & GOV6 & 0.1241 & 6 & 0.0285 & 20 \\
\hline \multirow[t]{5}{*}{ ECO } & ECO1 & 0.1762 & 3 & 0.0359 & 11 \\
\hline & $\mathrm{ECO} 2$ & 0.2602 & 1 & 0.0531 & 2 \\
\hline & $\mathrm{ECO} 3$ & 0.1540 & 5 & 0.0314 & 18 \\
\hline & ECO4 & 0.2449 & 2 & 0.0500 & 3 \\
\hline & ECO5 & 0.1647 & 4 & 0.0336 & 16 \\
\hline \multirow[t]{4}{*}{ SOC } & SOC1 & 0.3297 & 1 & 0.0553 & 1 \\
\hline & SOC2 & 0.2842 & 2 & 0.0477 & 5 \\
\hline & SOC3 & 0.2021 & 3 & 0.0339 & 15 \\
\hline & SOC4 & 0.1840 & 4 & 0.0309 & 19 \\
\hline \multirow[t]{6}{*}{ TECH } & TECH1 & 0.2286 & 1 & 0.0389 & 7 \\
\hline & TECH2 & 0.1870 & 2 & 0.0318 & 17 \\
\hline & TECH3 & 0.1554 & 3 & 0.0264 & 22 \\
\hline & TECH4 & 0.1486 & 4 & 0.0253 & 24 \\
\hline & TECH5 & 0.1454 & 5 & 0.0247 & 25 \\
\hline & TECH6 & 0.1351 & 6 & 0.0230 & 26 \\
\hline \multirow[t]{5}{*}{ ENV } & ENV1 & 0.2157 & 3 & 0.0343 & 14 \\
\hline & ENV2 & 0.2270 & 1 & 0.0360 & 10 \\
\hline & ENV3 & 0.1639 & 5 & 0.0260 & 23 \\
\hline & ENV4 & 0.2207 & 2 & 0.0350 & 13 \\
\hline & ENV5 & 0.1728 & 4 & 0.0274 & 21 \\
\hline \multirow[t]{5}{*}{ L\&E } & L\&E1 & 0.2128 & 4 & 0.0149 & 30 \\
\hline & L\&E2 & 0.2374 & 1 & 0.0166 & 27 \\
\hline & L\&E3 & 0.2215 & 2 & 0.0155 & 28 \\
\hline & L\&E4 & 0.2144 & 3 & 0.0150 & 29 \\
\hline & L\&E5 & 0.1139 & 5 & 0.0080 & 31 \\
\hline
\end{tabular}

\section{Sensitivity Analysis}

Generally, there is an immense imprecision and vagueness present in the data collection process. Sensitivity analysis monitors the priority ranking of the recognized barriers to smart cities development. Further, it has a tendency that can determine the smallest change in the ranking with the changes in relative weights of the barrier. In this sense, it is sensible to verify the priority ranks by altering the weights of all the categories of barriers (Mangla et al. 2015).

In this research, 'Governance (GOV)' category is the topmost ranked among all (see Table 6). This category would affect the other categories of barriers for smart city development. For that reason, we varied the 'Governance' category relative weights from values 0.1 to 0.9 and changes in the weights of other categories were noted correspondingly (see Table 8).

At 0.1 value of 'Governance' category, barrier SOC1 obtains the highest rank and barrier L\&E5 obtains the lowest rank. Barrier SOC1 retains the highest rank and barrier L\&E5 the lowest rank value until the normal value $(0.2295)$ for Governance category is reached. From varying the Governance category weights value (from 0.3 to 0.9 ), barrier GOV3 holds highest rank, and the ranking of other barriers also vary accordingly. The changes in the weights of specific barriers when Governance category weights change from 0.1 to 0.9 have been presented in Table 9 .

Global preference weight of the smart city development barriers based on sensitivity analysis is shown in Fig. 4 .

From Fig. 4, insignificant changes can be noticed in the global weights of barriers, and thus, the proposed framework 
Table 8 Values of category of barriers when increasing Governance category of barriers

\begin{tabular}{|l|c|c|c|c|c|c|c|c|c|c|}
\hline $\begin{array}{l}\text { Listed } \\
\text { categories }\end{array}$ & \multicolumn{9}{|l|}{$\begin{array}{l}\text { Values of preference weights for selected categories } \\
\end{array}$} \\
\hline GOV & 0.2295 & 0.1001 & 0.2001 & 0.3002 & 0.4001 & 0.5002 & 0.6007 & 0.7001 & 0.8002 & 0.9001 \\
\hline ECO & 0.2040 & 0.2383 & 0.2118 & 0.1853 & 0.1588 & 0.1323 & 0.1057 & 0.0794 & 0.0529 & 0.0265 \\
\hline SOC & 0.1678 & 0.1960 & 0.1742 & 0.1524 & 0.1307 & 0.1089 & 0.0870 & 0.0653 & 0.0435 & 0.0218 \\
\hline TECH & 0.1701 & 0.1987 & 0.1766 & 0.1545 & 0.1324 & 0.1103 & 0.0882 & 0.0662 & 0.0441 & 0.0221 \\
\hline ENV & 0.1588 & 0.1855 & 0.1649 & 0.1442 & 0.1236 & 0.1030 & 0.0823 & 0.0618 & 0.0412 & 0.0206 \\
\hline L\&E & 0.0698 & 0.0815 & 0.0725 & 0.0634 & 0.0543 & 0.0453 & 0.0362 & 0.0272 & 0.0181 & 0.0091 \\
\hline Total & 1 & 1 & 1 & 1 & 1 & 1 & 1 & 1 & 1 & 1 \\
\hline
\end{tabular}

is robust enough to deal with human subjectivity and uncertainty in data under fuzzy conditions.

\section{Discussion}

According to Table 6, the categories of barriers follow the order in priority as - Governance (GOV) - Economic (ECO) - Technology (TECH) - Social (SOC) - Environmental (ENV) - Legal and Ethical (L\&E). Governance (GOV) categories of barriers obtain the first rank. The implementation of smart city is highly context dependent (nations, government etc.) (Weisi and Ping 2014). Governance is one of key concerns in developing an efficient smart cities network. Thus, there is a higher need of better governance to manage several cities initiatives effectively (Chourabi et al. 2012). Within this category, 'Political instability (GOV3)' obtains the highest priority. Letaifa (2015) suggested that a smart city vision obstructed by political instability. Thus, leaders and practitioners should have a clear vision of the future; and make long-term plans, which could be only possible by political leadership and stability. 'Lack of cooperation and coordination between city's operational networks (GOV1)' is ranked after GOV3. There is a high need to promote cooperation and coordination between local authorities i.e. city's operational networks. 'Unclear IT management vision (GOV2)' comes next in the priority list. Chourabi et al. (2012) suggested that the integration of IT with development projects is crucial in smart city context. Next is 'Poor private-public participation (GOV5)' in this category. It means that policymakers should make efforts to promote private-public participations and investments for better governance in developing a smart city (Lee et al. 2014). 'Lack of trust between governed and government (GOV4)' comes after GOV5 according to their priority. Various researchers suggested that privacy and security issues are major concerns to develop trust between governed and government in the smart cities context. Khan et al. (2017) suggested in their research that user participation is crucial in managing smart cities data privacy and security related concerns to improve trust between governed and government. Finally, the 'Lack of developing a common information system model (GOV6)' stands last in the list. It means that common information system is modelled to collect city data to make meaningful decisions or actions in smart cities context.

Economic (ECO) category acquires second place among other barrier categories. Smart cities will require huge infrastructure, modern technologies, based on massive interconnected networks of sensors, screens, cameras, smart devices, smart grid etc. to analyse data and or information. Guy et al. (2011) concluded that infrastructure's development depends on government regulations and financial resources availability. This particular category has five specific barriers - 'Lack of competitiveness (ECO2)' obtains the utmost importance. This implies that urban areas need to be managed in such a way that leads to higher economic competitiveness, enhanced social security and ecological sustainability (Monzon 2015). However, the government fails to do that. Following this, the next is 'Global economy volatility (ECO4)' barrier in the list. Global economy volatility can influence the subsidies provided, and results in higher/lower greenhouse gas emissions. Subsequently, 'High IT infrastructure and intelligence deficit (ECO1)' shows that huge infrastructure and intelligent/ smart systems are required to develop smart cities. Nevertheless, it requires a lot of funds. The 'Higher operational and maintenance cost (ECO5)' barrier is next in terms of priority. Thus, technologists and practitioners must focus improving efficiency of the system for refining its sustainability (Mohanty et al. 2016). Finally, 'Cost of IT training and skills development (ECO3)' barrier is the last in the priority sequence i.e. smart city development requires higher IT training and skills, which is usually very costly.

Technology (TECH) acquired the third importance level among all the categories. Smart cities development needs higher research and technological innovations. There are different technological developments related to the IoT and Cloud computing in smart cities (Li et al. 2015; Petrolo et al. 2017; Whitmore et al. 2015). Li et al. (2015) and Whitmore et al. (2015) quoted in their research that IoT technologies will play key role in making cities more efficient and improving the lives of citizens. In this particular category, 'Lacking 
Table 9 Relative weights of barriers by sensitivity analysis when 'Governance' category weights change from 0.1 to 0.9 $\mathrm{GOV}=0.1 \quad \mathrm{GOV}=0.2 \quad \mathrm{GOV}=0.2295 \quad \mathrm{GOV}=0.3 \quad \mathrm{GOV}=0.4 \quad \mathrm{GOV}=0.5 \quad \mathrm{GOV}=0.6 \quad \mathrm{GOV}=0.7 \quad$ GOV $=0.8 \quad$ GOV $=0.9$ (Normal)

\begin{tabular}{|c|c|c|c|c|c|c|c|c|c|c|}
\hline GOV1 & 0.0183 & 0.0367 & 0.0420 & 0.0550 & 0.0733 & 0.0916 & 0.1099 & 0.1282 & 0.1466 & 0.1649 \\
\hline GOV2 & 0.0164 & 0.0327 & 0.0375 & 0.0491 & 0.0654 & 0.0818 & 0.0981 & 0.1145 & 0.1308 & 0.1472 \\
\hline GOV3 & 0.0215 & 0.0430 & 0.0494 & 0.0645 & 0.0860 & 0.1076 & 0.1291 & 0.1506 & 0.1721 & 0.1936 \\
\hline GOV4 & 0.0155 & 0.0310 & 0.0355 & 0.0465 & 0.0620 & 0.0775 & 0.0929 & 0.1084 & 0.1239 & 0.1394 \\
\hline GOV5 & 0.0159 & 0.0319 & 0.0366 & 0.0478 & 0.0637 & 0.0797 & 0.0956 & 0.1115 & 0.1274 & 0.1434 \\
\hline GOV6 & 0.0124 & 0.0248 & 0.0285 & 0.0372 & 0.0496 & 0.0621 & 0.0745 & 0.0869 & 0.0993 & 0.1117 \\
\hline ECO1 & 0.0420 & 0.0373 & 0.0359 & 0.0326 & 0.0280 & 0.0233 & 0.0186 & 0.0140 & 0.0093 & 0.0047 \\
\hline $\mathrm{ECO} 2$ & 0.0620 & 0.0551 & 0.0531 & 0.0482 & 0.0413 & 0.0344 & 0.0275 & 0.0207 & 0.0138 & 0.0069 \\
\hline ECO3 & 0.0367 & 0.0326 & 0.0314 & 0.0285 & 0.0245 & 0.0204 & 0.0163 & 0.0122 & 0.0081 & 0.0041 \\
\hline ECO4 & 0.0584 & 0.0519 & 0.0500 & 0.0454 & 0.0389 & 0.0324 & 0.0259 & 0.0194 & 0.0130 & 0.0065 \\
\hline ECO5 & 0.0392 & 0.0349 & 0.0336 & 0.0305 & 0.0262 & 0.0218 & 0.0174 & 0.0131 & 0.0087 & 0.0044 \\
\hline SOC1 & 0.0646 & 0.0574 & 0.0553 & 0.0502 & 0.0431 & 0.0359 & 0.0287 & 0.0215 & 0.0143 & 0.0072 \\
\hline $\mathrm{SOC} 2$ & 0.0557 & 0.0495 & 0.0477 & 0.0433 & 0.0371 & 0.0309 & 0.0247 & 0.0186 & 0.0124 & 0.0062 \\
\hline SOC3 & 0.0396 & 0.0352 & 0.0339 & 0.0308 & 0.0264 & 0.0220 & 0.0176 & 0.0132 & 0.0088 & 0.0044 \\
\hline SOC4 & 0.0361 & 0.0321 & 0.0309 & 0.0280 & 0.0240 & 0.0200 & 0.0160 & 0.0120 & 0.0080 & 0.0040 \\
\hline TECH1 & 0.0454 & 0.0404 & 0.0389 & 0.0353 & 0.0303 & 0.0252 & 0.0202 & 0.0151 & 0.0101 & 0.0050 \\
\hline TECH2 & 0.0372 & 0.0330 & 0.0318 & 0.0289 & 0.0248 & 0.0206 & 0.0165 & 0.0124 & 0.0083 & 0.0041 \\
\hline TECH3 & 0.0309 & 0.0274 & 0.0264 & 0.0240 & 0.0206 & 0.0171 & 0.0137 & 0.0103 & 0.0069 & 0.0034 \\
\hline TECH4 & 0.0295 & 0.0262 & 0.0253 & 0.0230 & 0.0197 & 0.0164 & 0.0131 & 0.0098 & 0.0066 & 0.0033 \\
\hline TECH5 & 0.0289 & 0.0257 & 0.0247 & 0.0225 & 0.0193 & 0.0160 & 0.0128 & 0.0096 & 0.0064 & 0.0032 \\
\hline TECH6 & 0.0268 & 0.0239 & 0.0230 & 0.0209 & 0.0179 & 0.0149 & 0.0119 & 0.0089 & 0.0060 & 0.0030 \\
\hline ENV1 & 0.0400 & 0.0356 & 0.0343 & 0.0311 & 0.0267 & 0.0222 & 0.0178 & 0.0133 & 0.0089 & 0.0044 \\
\hline ENV2 & 0.0421 & 0.0374 & 0.0360 & 0.0327 & 0.0281 & 0.0234 & 0.0187 & 0.0140 & 0.0093 & 0.0047 \\
\hline ENV3 & 0.0304 & 0.0270 & 0.0260 & 0.0236 & 0.0203 & 0.0169 & 0.0135 & 0.0101 & 0.0068 & 0.0034 \\
\hline ENV4 & 0.0409 & 0.0364 & 0.0350 & 0.0318 & 0.0273 & 0.0227 & 0.0182 & 0.0136 & 0.0091 & 0.0045 \\
\hline ENV5 & 0.0320 & 0.0285 & 0.0274 & 0.0249 & 0.0214 & 0.0178 & 0.0142 & 0.0107 & 0.0071 & 0.0036 \\
\hline L\&E1 & 0.0173 & 0.0154 & 0.0149 & 0.0135 & 0.0116 & 0.0096 & 0.0077 & 0.0058 & 0.0039 & 0.0019 \\
\hline L\&E2 & 0.0194 & 0.0172 & 0.0166 & 0.0151 & 0.0129 & 0.0107 & 0.0086 & 0.0064 & 0.0043 & 0.0021 \\
\hline L\&E3 & 0.0181 & 0.0161 & 0.0155 & 0.0140 & 0.0120 & 0.0100 & 0.0080 & 0.0060 & 0.0040 & 0.0020 \\
\hline L\&E4 & 0.0175 & 0.0155 & 0.0150 & 0.0136 & 0.0117 & 0.0097 & 0.0078 & 0.0058 & 0.0039 & 0.0019 \\
\hline L\&E5 & 0.0093 & 0.0083 & 0.0080 & 0.0072 & 0.0062 & 0.0052 & 0.0041 & 0.0031 & 0.0021 & 0.0010 \\
\hline
\end{tabular}

technological knowledge among the planners (TECH1)' barrier holds the highest priority. In respect to developing a smart city, it requires technological knowledge among the planners (Letaifa 2015), as 'Lack of access to technology (TECH2)'
Fig. 4 Sensitivity analysis of barriers to smart city development

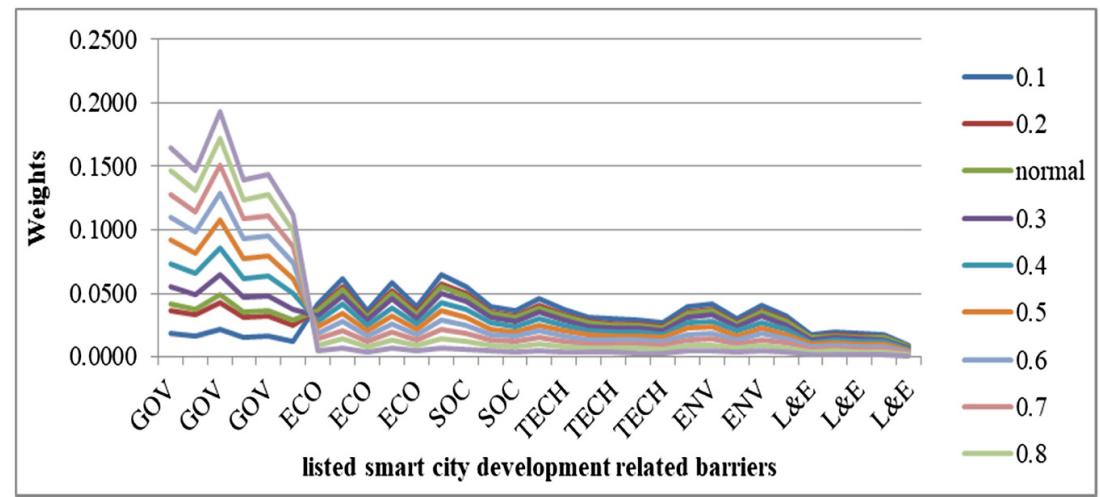


barrier comes next to TECH1. Monzon (2015) suggested that a majority of the population living in these cities lack the access to technology. Hence, policymakers should make available the necessary technology and arrange training programs to educate the citizens for its accurate usage. Next, 'Privacy and security issues (TECH3)' comes in this category of barriers to smart city development. Many researchers highlighted the privacy and security issues in smart cities context (Elmaghraby and Losavio 2014; Belanche-Gracia et al. 2015; van Zoonen 2016; Zhang et al. 2017). 'System failures issues (TECH4)' barrier comes next. Colding and Barthel (2017) suggested smart city network is highly vulnerable so as provide ample room for cyber-attacks of different kinds and other forms of incidents such as industrial espionage, terrorists, equipment failures, worm infestations and natural disasters. Next to this is 'Integration and convergence issues across IT networks (TECH5)' barrier to smart city development. Smart cities require various heterogeneous components to communicate, but in designing, a flexible interface to integrate these heterogeneous components is challenging. Cyber physical networks need to be integrated and supported for an effective data exchange and analysis in smart cities environment. Finally, 'Poor data availability and scalability (TECH6)' is last in the list. Santana et al. (2017) suggested that policy planners should address the issues related to data quality and its scalability in smart city context. Janssen et al. (2017) and Pereira et al. (2017) revealed in their research that big open data initiatives can help in providing real-time weather forecast, pollution and traffic management, creating transparency, better decision and policy-making and crisis management etc., and contribute to enhance the delivery of public value in smart city contexts.

Social (SOC) category of barriers occupies next place in the main priority list. There are several social concerns in developing of smart cities, such as public health and safety, education, and hospital facilities (Solanas et al. 2014). Policymakers need to deal with the social challenges in smart cities development. Colding and Barthel (2017) stipluated that there are multiple socio-economic challenges with massive demographic transition; detrimental environmental impacts may also follow unless adequate measures are taken. This category has four specific barriers to smart city development. 'Lack of involvement of citizens (SOC1)' is the top ranked barrier in this category. This could be validated from the research of Yang and Callahan (2007) that citizens are often criticized due to their low interest and participation. In this sense, policymakers should encourage citizens to contribute in decision-making processes for a sustainable city. Afterwards, 'Low awareness level of community (SOC2)' barrier comes in this category. It means that community engagement is very important for planning and implementing smart cities initiatives. Next to this is 'Geographical diversification problems (SOC3)' barrier to smart cities development.
In India, with a high geographical diversity, needs large amount of data to analyse urban issues and other geographical processes (Batty 2012; Liu et al. 2016). Finally, 'Degree of inequality (SOC4)' is last in the hierarchy list of barriers to smart cities development. Therefore, inequalities among the citizens must be reduced to plan smart cities initiatives.

Environmental (ENV) category of barriers occupies fifth place in the priority list. Thus, practitioners, policymakers and citizens must focus to observe various ecological parameters like air pollution, temperature, vibrations, and noise and make humans consume less energy and water, and even reduce greenhouse gas emissions etc. (Colding and Barthel 2017). This category has five specific barriers. 'Growing population problems (ENV2)' is at the top ranking. In India, the urbanisation is growing rapidly, and cities are likely to expand to 600 million by 2030 . Higher population needs more resources to fulfil their requirements (Albino et al. 2015). Subsequently, 'Carbon emissions effect (ENV4)' is the next to come in this category. Sadorsky (2014) pointed out that growing urbanization leads to higher carbon emissions and results in lower sustainability. 'Lacking ecological view in behaviour (ENV1)' comes next. It means that a holistic approach should be adapted to promote ecological view in behaviour in citizens. Next to this is 'Degradation of resources (ENV5)' to smart cities development. Finally, 'Lack of sustainability considerations (ENV3)' is at the end in the list. Policy planners are suggested to include sustainability aspects while designing smart city networks for higher ecological benefits (Luthra et al. 2015).

Legal and Ethical (L\&E) category of barriers holds the last place in priority list. Kitchin (2015) affirmed that there are several social, ethical and legal issues linked to a smart city initiative. Within this particular category, 'Lacking standardization (L\&E2)' barrier is ranked first. Clearly, there is a lack of standards and policy directions on efficient applicability and managing of IoT based networks (Weber 2013; Perera et al. 2014; Zanella et al. 2014; Weber and Studer 2016). 'Issues of openness of data (L\&E3)' comes next to the list. Rathore et al. (2016) identified the issues of openness of data are crucial in the smart city agenda. Enabling openness of real time data will help the government authorities as well as citizens. The next barrier i.e. 'Lack of transparency and liability (L\&E4)' indicates that higher public involvement and superior transparency in governance is critical in smart cities development (Kandpal et al. 2017). Next barrier in this list is 'Cultural issues (L\&E1)' to smart cities development. Last in the priority list is 'Lack of regulatory norms, policies and directions (L\&E5)'. Well-defined regulating norms, polices and directions are needed that help in keeping the user-friendliness to the data users and monitoring all the stakeholders and parties being a part of the system.

Further, we identified the global ranking of barriers to smart city development. According to global ranking of 
barriers, 'Lack of involvement of citizens (SOC1)'; 'Lack of competitiveness (ECO2)'; 'Global economy volatility (ECO4)'; 'Political instability (GOV3)' and 'Low awareness level of community (SOC2)' have been recognized as top five barriers to smart cities development in Indian context.

\subsection{Theoretical Contributions}

The present work has several unique contributions, given as follow:

- This study reveals 31 key barriers within 6 categories to smart city development in developing economies, especially in India. The recognized barriers would facilitate policy makers in development of efficient smart city network in India. However, in the context of contributing to the theory, the explicit process of fuzzy AHP technique is provided to prioritise the barriers. The proposed research framework is logically sound in analysing the smart city development barriers.

- This study seeks to know the relative importance of barriers in smart city development. This research work offers an in-depth understanding of barriers, with a focus on smart city development, for devising both the plan of action and the suggestive measures in dealing smart city barriers effectively.

\subsection{Implications to Practice and Policy}

This research is useful to the policymakers who are engaged with smart cities development initiatives in developing countries as India as this help government to understand the probable hindrances in successful adoption of smart city in practice. This work offers following important implications for the government and policymakers.

\subsubsection{Role of Better Governance and Effective Decision-Making}

The role of governance is prominent in developing smart cities within a country. Better governance will help to better coordination between central, state governments and parties involved in smart cities development to increasing the effectiveness of smart cities related policy decisions and involvement of the public. Government policymakers and practitioners may promote e-governance services to bring about accountability and transparency in decision-making process, which will help smart governance in developing smart cities.

\subsubsection{Provision of Higher Resources and Infrastructure}

This is important for the management of resources, such as equipment and humans required for performing the intended functions in developing smart cities. Funding and developing infrastructure for smart cities projects remains a challenge, therefore governments must focus on creative solutions and participation by both the public and private sectors. Consequently, having adequate funds and resources allocated are crucial in smart cities initiatives. This research may help removing resources and infrastructure related challenges.

\subsubsection{Technological Advancements}

In a truly smart city of the future, hyper connection and automation will be paramount. This capability will be dependent on integrating advanced information technologies such as IoT. IoT will help to i) manage infrastructure decisions; ii) improve service level of the end users; iii) enhance levels of crosssector collaboration and iv) map government policies to deal with climate change related problems.

\subsubsection{Awareness among Community}

In developing smart cities, smart community development is necessary. Currently, the involvement of community is less integral in smart cities development, particularly in India. It is important to develop an efficient IT infrastructure by aligning the skills and expertise of people involved in the system. Therefore, practitioners and policymakers must focus on smart community planning to act as a catalyst in solving key issues such as environment, transport and security.

\subsubsection{Higher Ecological Performance and Sustainable Development}

Smart city development puts greater pressure on resource consumption, infrastructure, and development practices, which may have a negative impact on the environment. Threfore, it is crucial to measure and assess/evaluate? policies, infrastructure, socio-economic factors, resource use, emissions and any other processes that contribute to quality of life. Hence, logical planning is needed to address social and ecological sustainability challenges in smart city development.

\section{Conclusion}

Smart city development is gaining considerable recognition in the systematic literature and international policies in the last two decades. The present research seeks to recognise and prioritise barriers linked to smart city development to help policymakers in improving their sustainability in an Indian 
context. In this work, we used fuzzy AHP to demonstrate the importance of the potential barriers under fuzzy surroundings. A comprehensive review of keywords across various literature surveys disclosed 31 key barriers to smart cities development. These barriers were also confirmed further through a panel of experts. We categorised these barriers into six key categories with experts' consultation. The findings revealed 'Governance' is documented as the most significant category of barriers for smart city development followed by barriers related to 'Economic; 'Technology'; 'Social'; 'Environmental' and 'Legal and Ethical' categories. The relative and global preference weights of specific barriers are also determined. The sensitivity analysis is performed to verify the stability of the findings obtained in this study. This research is useful to the government and policymakers for eradicating the potential interferences in smart city development initiatives in developing countries like India.

\subsection{Limitations and Future Scope}

This work has its own limitations. Firstly, the findings of this study are highly influenced by experts' opinions. The developed solution model may be adopted in other developing countries with minor modifications. Secondly, this research is limited to identifing and prioritising the barriers of smart cities development under six broader categories. The recognised barriers may be evaluated further to know their causal relations in smart city development initiatives through DEMATEL/Fuzzy DEMATEL/Grey DEMATEL techniques. There is also a further scope to develop research based on drivers of smart cities development. Therefore, the future research could explore the prioritisation of the drivers. This could provide a useful prescription for policymakers to implement in addition to consideration of this research. Moreover, the researchers could also consider implementing ISM methodology (Al-Muftah et al. 2018; Dwivedi et al. 2017a; Hughes et al. 2016; Janssen et al. 2018) to understand the driving and dependent barriers. The citizens are one of the most important stakeholders of such developments. Hence, in order to avoid resistance from stakeholders and failure of such initiatives (Dwivedi et al. 2015; Hughes et al. 2016, 2017), the perceptions of citizens and government employees towards various aspects of smart cities should also be explored by utilising established theories and models (see for example, AlAlwan et al. 2017; Dwivedi et al. 2011a, 2011b, 2013, 2016, 2017b, 2017c; Hossain and Dwivedi 2014; Kapoor et al. 2014a, 2014b, 2015; Rana and Dwivedi 2015; Rana et al. 2015a, 2015b, 2016, 2017; Shareef et al. 2011, 2016a, 2016b, 2017; Sinha et al. 2017; Slade et al. 2015; Veeramootoo et al. 2018; Weerakkody et al. 2013, 2017) from information systems and electronic government domains.

\section{Appendix}

The calculation procedure of extent analysis method as described by Luthra et al. (2015) and Mangla et al. (2015) is described as below:

The extent analysis values for the $\mathrm{i}^{\text {th }}$ object is represented by $\mathrm{O}_{\mathrm{g}_{\mathrm{i}}}^{1}, \mathrm{O}_{\mathrm{g}_{\mathrm{i}}}^{2}, \mathrm{O}_{\mathrm{g}_{\mathrm{i}}}^{3}, \ldots \ldots . . \mathrm{O}_{\mathrm{g}_{\mathrm{i}}}^{\mathrm{p}}$, Consequently, the fuzzy synthetic extent values are represented as given in below expression.

$\mathrm{S}_{\mathrm{i}}=\sum_{\mathrm{j}=1}^{\mathrm{o}} \mathrm{O}_{\mathrm{g}_{\mathrm{i}}}^{\mathrm{j}} \times\left[\sum_{\mathrm{i}=1}^{\mathrm{n}} \sum_{\mathrm{j}=1}^{\mathrm{o}} \mathrm{O}_{\mathrm{g}_{\mathrm{i}}}^{\mathrm{j}}\right]$

For taking the minimum and maximum values for fuzzy number, the degree of possibility is determined as given in below expression:

$V\left(O_{1} \geq O_{2}\right)=\sup \left[\min \left(\mu_{O_{1}}(\mathrm{x}) \mu_{O_{2}}(\mathrm{y})\right)\right] ; \mathrm{x}, \mathrm{y} \in \mathrm{R}$, and $\mathrm{x} \geq \mathrm{y}$

If, $\mathrm{x} \geq \mathrm{y}$ and $\mathrm{f}_{O_{1}}(\mathrm{x})=\mathrm{f}_{O_{2}}(\mathrm{y})=1$, then $\mathrm{V}\left(O_{1} \geq O_{2}\right)=1$.

Notably, $\mathrm{O}_{1}$ and $\mathrm{O}_{2}$ are two convex fuzzy numbers, and they must satisfy the following conditions:

$\mathrm{V}\left(\mathrm{O}_{1} \geq \mathrm{O}_{2}\right)=1 \quad$ if $\mathrm{o}_{1} \geq \mathrm{o}_{2}$

$\mathrm{V}\left(\mathrm{O}_{1} \geq \mathrm{O}_{2}\right)=\operatorname{hgt}\left(\mathrm{O}_{1} \cap \mathrm{O}_{2}\right)=\mathrm{f}_{\mathrm{o}_{1}}(\mathrm{~m})$

Next, ' $m$ ' denotes the ordinate of the highest intersection point $\mathrm{M}$ between the membership functions of two fuzzy numbers. Hence, $\mathrm{M}$ is given as:

$\mathrm{V}\left(\mathrm{O}_{1} \geq \mathrm{O}_{2}\right)=\operatorname{hgt}\left(\mathrm{O}_{1} \cap \mathrm{O}_{2}\right)=(\mathrm{a}-\mathrm{r}) /(\mathrm{q}-\mathrm{r})-(\mathrm{b}-\mathrm{a})$

While the degree of possibility for ' $k$ ' convex fuzzy numbers $\mathrm{O}_{\mathrm{i}}(\mathrm{i}=1,2 \ldots \ldots \ldots \mathrm{k})$ can be determined form the following expression:

$$
\begin{aligned}
\mathrm{V} & \left(\mathrm{O} \geq \mathrm{O}_{1}, \mathrm{O}_{2}, \ldots \ldots \ldots \mathrm{O}_{\mathrm{k}}\right) \\
& =\mathrm{V}\left[\left(\mathrm{O} \geq \mathrm{O}_{1}\right) \text { and }\left(\mathrm{O} \geq \mathrm{O}_{2}\right) \text { and } \ldots \ldots \ldots . . . \text { and }\left(\mathrm{O} \geq \mathrm{O}_{\mathrm{k}}\right)\right] \\
& =\operatorname{minV}\left(\mathrm{O} \geq \mathrm{O}_{\mathrm{i}}\right), \mathrm{i}=1,2,3, \ldots \ldots \ldots \ldots \ldots . \mathrm{k} .
\end{aligned}
$$

Next, we assume $z^{\prime}\left(C_{i}\right)=\min V\left(S_{i} \geq S_{k}\right)$, for $k=1,2, \ldots \ldots, n$; $\mathrm{k} \neq \mathrm{i}$; the weight vector in that case is given as:

$$
\mathrm{W}^{\prime}=\left(\mathrm{z}^{\prime}\left(\mathrm{C}_{1}\right),\left(\mathrm{C}_{1}\right),\left(\mathrm{C}_{1}\right) \ldots \ldots \ldots \ldots\left(\mathrm{C}_{1}\right)\right)^{\mathrm{T}} \text {; Where } \mathrm{C}_{\mathrm{i}}(i=1 \text {, }
$$
2......n) are the elements.

For normalization, the below highlighted expression is used. While, 'W' is a non-fuzzy number.

$$
\mathrm{W}=\left(\mathrm{z}^{\prime}\left(\mathrm{C}_{1}\right),\left(\mathrm{C}_{1}\right),\left(\mathrm{C}_{1}\right) \ldots \ldots \ldots . .\left(\mathrm{C}_{1}\right)\right)^{\mathrm{T}}
$$

\section{Survey Questionnaire}

This questionnaire consists of three sections. Section [A] deals with the general information of the respondents and their respective background where they work. Section B helps in 
selecting the most suitable barriers and exploring their significance to smart cities development. Section C assists in examining the priority of concern of the selected barriers.

\section{Section [A]: General Information}

Please highlight only one choice in each question as follows:

1. What is your professional qualification?
(a) Graduate
(b) Post Graduate
(c) Doctorate
(d) If any other, please specify

2. What is your work experience?
(a) Less than 5 Years
(b) 5 to 10 Years
(c) 11 to 15 Years
(d) 16 to 20 Years
(e) Greater than 20 Years

3. What is the size of your organization?
(a) Less than 50 Employees
(b) 51 to 250 Employees
(c) 251-500 Employees
(d) 501-1000 employees
(e) 1001-5000 employees
(f) Greater than 5001 employees

4. How will you classify work profile?
(a) Private Sector
(b) Public Sector
(c) Multinational Corporation
(d) Regulatory Bodies
(e) Mixed public and private ownership
(f) If any other, please specify

\section{Section [B]: The Most Relevant Barriers in Smart Cities Development in India}

Please rate the following barriers on 5-point Likert scale (' 1 'Not significant, '2'-Somewhat significant, '3'-Significant, '4'-Very significant, and ' 5 '-Extremely significant). Further, you are also free to add any specific barrier within any main category, which you think, should be included into the list.

\footnotetext{
S. No. Barriers to Smart Cities

Governance (GOV)

1 Lack of cooperation and coordination between city's operational networks (GOV1)

2 Unclear IT management vision (GOV2)

3 Political instability (GOV3)

$4 \quad$ Lack of trust between governed and government (GOV4)

$5 \quad$ Poor private-public participation (GOV5)

$6 \quad$ Lack of developing a common information system model (GOV6)

Please add any other barrier (in your opinion)

Economic (ECO)

$7 \quad$ High IT infrastructure and intelligence deficit (ECO1)

$8 \quad$ Lack of competitiveness (ECO2)

9 Cost of IT training and skills development (ECO3)

10 Global economy volatility (ECO4)

11 Higher operational and maintenance cost (ECO5)

Please add any other barrier (in your opinion)

Social (SOC)

12 Lack of involvement of citizens (SOC1)

13 Low awareness level of community (SOC2)

14 Geographical diversification problems (SOC3)

15 Degree of inequality (SOC4)

Please add any other barrier (in your opinion)

Technology (TECH)
}

Response [In 5-Point Likert Scale] 
16 Lacking technological knowledge among the planners (TECH1)

17 Lack of access to technology (TECH2)

$18 \quad$ Privacy and security issues (TECH3)

19 System failures issues (TECH4)

20 Integration and convergence issues across IT networks (TECH5)

$21 \quad$ Poor data availability and scalability (TECH6)

Please add any other barrier (in your opinion)

Environmental (ENV)

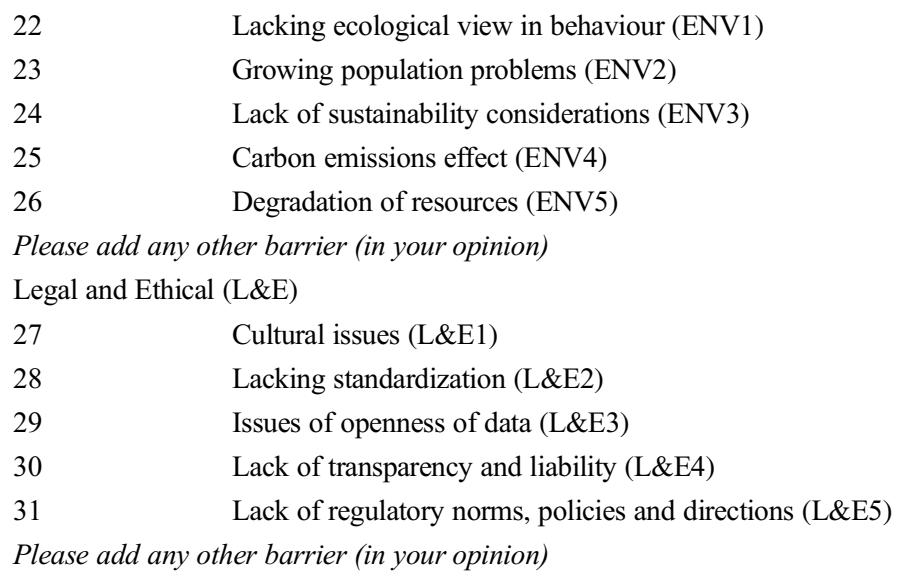

Please add any other barrier (in your opinion)

Barriers to smart cities development in India as reported in the literature

\section{Section C: Analysing Identified Barriers to Determine Their Priority for Concern}

After finalizing the key barriers to develop smart cities, author would analyse them to priority for concern (their relative importance). For determining their priority, it needs to construct the pair wise evaluation matrix for the identified main barriers and for the specific barriers as well. In view of that, please put your response in the pairwise evaluation matrices both for the key categories of barriers and specific barriers. Please use the given fuzzy linguistic scale for entering your responses.

Fuzzy linguistic scale for forming pairwise evaluation matrix.

\begin{tabular}{ll}
\hline Uncertain judgment & Fuzzy score \\
\hline Almost equivalent & $1 / 2,1,2$ \\
Almost $x$ times more important & $\mathrm{x}-1, \mathrm{x}, \mathrm{x}+1$ \\
Almost $\mathrm{x}$ times less important & $1 / \mathrm{x}+1,1 / \mathrm{x}, 1 / \mathrm{x}-1$ \\
Between y and $\mathrm{z}$ times more important & $\mathrm{y},(\mathrm{y}+\mathrm{z}) / 2, \mathrm{z}$ \\
Between y and $\mathrm{z}$ times less important & $1 / \mathrm{z}, 2 /(\mathrm{y}+\mathrm{z}), 1 / \mathrm{y}$ \\
\hline
\end{tabular}

Note: The value of $\mathrm{x}$ ranges from $2,3 \ldots 9$; whereas the values of $\mathrm{y}$ and $\mathrm{z}$ can be $1,2 \ldots . .9$, with $y<z$
Pairwise evaluation matrix for main barriers.

\begin{tabular}{lllllll}
\hline & GOV & ECO & SOC & TECH & ENV & L\&E \\
\hline GOV & $(1,1,1)$ & & & & & \\
ECO & & $(1,1,1)$ & & & & \\
SOC & & & $(1,1,1)$ & & & \\
TECH & & & & $(1,1,1)$ & & \\
ENV & & & & & $(1,1,1)$ & \\
L\&E & & & & & & $(1,1,1)$ \\
\hline
\end{tabular}

Pairwise evaluation matrix for specific barriers.

\begin{tabular}{lccccccc}
\hline & GOV1 & GOV2 & GOV3 & GOV4 & GOV5 & GOV6 & $\begin{array}{c}\text { Additional } \\
\text { Barrier }\end{array}$ \\
\hline GOV1 & $(1,1,1)$ & & & & & & \\
GOV2 & & $(1,1,1)$ & & & & & \\
GOV3 & & & $(1,1,1)$ & & & & \\
GOV4 & & & & $(1,1,1)$ & & & \\
GOV5 & & & & & $(1,1,1)$ & & \\
GOV6 & & & & & & $(1,1,1)$ & \\
Additional & & & & & & & \\
Barrier & & & & & & & \\
\hline
\end{tabular}


Pairwise evaluation matrix for specific barriers.

\begin{tabular}{lcccccc}
\hline & ECO1 & ECO2 & ECO3 & ECO4 & ECO5 & $\begin{array}{c}\text { Additional } \\
\text { Barrier }\end{array}$ \\
\hline ECO1 & $(1,1,1)$ & & & & & \\
ECO2 & & $(1,1,1)$ & & & \\
ECO3 & & & $(1,1,1)$ & & \\
ECO4 & & & & $(1,1,1)$ & \\
ECO5 & & & & & $(1,1,1)$ & \\
Additional & & & & & \\
Barrier & & & & & \\
\hline
\end{tabular}

Pairwise evaluation matrix for specific barriers.

\begin{tabular}{|c|c|c|c|c|c|}
\hline & SOC1 & SOC2 & SOC3 & SOC4 & Additional Barrier \\
\hline SOC1 & $(1,1,1)$ & & & & \\
\hline $\mathrm{SOC} 2$ & & $(1,1,1)$ & & & \\
\hline SOC3 & & & $(1,1,1)$ & & \\
\hline SOC4 & & & & $(1,1,1)$ & \\
\hline Additional Barrier & & & & & \\
\hline
\end{tabular}

Pairwise evaluation matrix for specific barriers.

\begin{tabular}{lccccccc}
\hline & TECH1 & TECH2 & TECH3 & TECH4 & TECH5 & TECH6 & $\begin{array}{c}\text { Additional } \\
\text { Barrier }\end{array}$ \\
\hline TECH1 & $(1,1,1)$ & & & & & & \\
TECH2 & & $(1,1,1)$ & & & & & \\
TECH3 & & & $(1,1,1)$ & & & & \\
TECH4 & & & & $(1,1,1)$ & & & \\
TECH5 & & & & & $(1,1,1)$ & & $(1,1,1)$ \\
TECH6 & & & & & & & \\
Additional & & & & & & \\
$\quad$ Barrier & & & & & & \\
\hline
\end{tabular}

Pairwise evaluation matrix for specific barriers.

\begin{tabular}{|c|c|c|c|c|c|c|}
\hline & ENV1 & ENV2 & ENV3 & ENV4 & ENV5 & $\begin{array}{c}\text { Additional } \\
\text { Barrier }\end{array}$ \\
\hline ENV1 & $(1,1,1)$ & & & & & \\
\hline ENV2 & & $(1,1,1)$ & & & & \\
\hline ENV3 & & & $(1,1,1)$ & & & \\
\hline ENV4 & & & & $(1,1,1)$ & & \\
\hline ENV5 & & & & & $(1,1,1)$ & \\
\hline $\begin{array}{c}\text { Additional } \\
\text { Barrier }\end{array}$ & & & & & & \\
\hline
\end{tabular}

Pairwise evaluation matrix for specific barriers.

\begin{tabular}{|c|c|c|c|c|c|c|}
\hline & L\&E1 & L\&E2 & L\&E3 & L\&E4 & L\&E5 & $\begin{array}{c}\text { Additional } \\
\text { Barrier }\end{array}$ \\
\hline L\&E1 & $(1,1,1)$ & & & & & \\
\hline L\&E2 & & $(1,1,1)$ & & & & \\
\hline L\&E3 & & & $(1,1,1)$ & & & \\
\hline L\&E4 & & & & $(1,1,1)$ & & \\
\hline L\&E5 & & & & & $(1,1,1)$ & \\
\hline $\begin{array}{c}\text { Additional } \\
\text { Barrier }\end{array}$ & & & & & & \\
\hline
\end{tabular}

Open Access This article is distributed under the terms of the Creative Commons Attribution 4.0 International License (http:// creativecommons.org/licenses/by/4.0/), which permits unrestricted use, distribution, and reproduction in any medium, provided you give appropriate credit to the original author(s) and the source, provide a link to the Creative Commons license, and indicate if changes were made.

\section{References}

Aijaz, R. (2016). Challenge of making smart cities in India. IFRI Center of Asian Studies. Asie Visions. 1-34. Available at: https://www.ifri. org/sites/default/files/atoms/files/av87_smart_cities_india_aijaz_0. pdf (Last accessed: January 24, 2018).

AlAlwan, A., Dwivedi, Y. K., \& Rana, N. P. (2017). Factors influencing adoption of mobile banking by Jordanian Bank customers: Extending UTAUT2 with trust. International Journal of Information Management, 37(3), 99-110.

Alawadhi, S., Aldama-Nalda, A., Chourabi, H., Gil-García, J., Leung, S., Mellouli, S., Nam, T., Pardo, T. A., Scholl, H. J. and Walker, S. (2012). Building understanding of smart city initiatives. Electronic Government, 40-53.

Albino, V., Berardi, U., \& Dangelico, R. M. (2015). Smart cities: Definitions, dimensions, performance, and initiatives. Journal of Urban Technology, 22(1), 3-21.

Al-Muftah, H., Weerakkody, V., Rana, N.P., Sivarajah, U., and Irani, Z. (2018). E-diplomacy Implementation: Exploring Causal Relationships Using Interpretive Structural Modelling. Government Information Quarterly, https://doi.org/10.1016/j.giq. 2018.03.002.

Angelidou, M. (2015). Smart cities: A conjuncture of four forces. Cities, $47,95-106$.

Bakıcı, T., Almirall, E., \& Wareham, J. (2013). A smart city initiative: The case of Barcelona. Journal of the Knowledge Economy, 4(2), 135148.

Ballon, P., Glidden, J., Kranas, P., Menychtas, A., Ruston, S. and Van Der Graaf, S. (2011). Is there a need for a cloud platform for European smart cities? In eChallenges e-2011 Conference Proceedings on IIMC International Information Management Corporation, 1-7.

Balta-Ozkan, N., Davidson, R., Bicket, M., \& Whitmarsh, L. (2013). Social barriers to the adoption of smart homes. Energy Policy, 63, 363-374.

Batty, M. (2012). Smart cities, big data. Centre for advanced spatial analysis. Available at: http://www.spatialcomplexity.info/files/2014/03/ BATTY-TECHNION1.pdf (Accessed on: January 19, 2018). 
Belanche-Gracia, D., Casalo-Arino, L. V., \& Pérez-Rueda, A. (2015). Determinants of multi-service smartcard success for smart cities development: A study based on citizens' privacy and security perceptions. Government Information Quarterly, 32(2), 154-163.

Bhattacharya, S., Rathi, S., Patro, S.A., Tepa, N. (2015). Reconceptualising smart cities: A reference framework for India. CSTEP. Available at: http://niti.gov.in/writereaddata/files/ document publication/CSTEP\%20Report\%20 Smart\%20Cities\% 20Framework.pdf (Last accessed: December 16, 2017).

Bloomberg Philanthropies (2017). India smart cities mission. Available at: https://www.bloomberg.org/program/government-innovation/ india-smart-cities-mission (Last accessed: August 02, 2017).

Chan, F. T., Kumar, N., Tiwari, M. K., Lau, H. C., \& Choy, K. L. (2008). Global supplier selection: A fuzzy-AHP approach. International Journal of Production Research, 46(14), 3825-3857.

Chang, D. Y. (1996). Applications of the extent analysis method on fuzzy AHP. European Journal of Operational Research, 95(3), 649-655.

Chatterjee, S., \& Kar, A. K. (2018a). Readiness of Smart City: Emerging economy perspective. Advances in Theory and Practice of Emerging Markets, 2, 221-232.

Chatterjee, S., \& Kar, A. K. (2018b). Alignment of IT authority and citizens of proposed smart cities in India: System security and privacy perspective. Global Journal of Flexible Systems Management, 19(1), 95-107.

Chatterjee, S., Kar, A.K. \& Gupta, M.P. (2018). Success of IoTin smart cities of India: An empirical analysis. Forthcoming in Government Information Quarterly.

Chauhan, S., Agarwal, N., \& Kar, A. K. (2016). Addressing big data challenges in smart cities: A systematic literature review. info, 18(4), 73-90.

China Daily (2013). 'Smart city' takes shape in Xinjiang. Available at: http://www.chinadaily.com.cn/ china/2012cpc /2012-11/14/content_15925234.htm (Last accessed: December 23, 2017).

Chourabi, H., Nam, T., Walker, S., Gil-Garcia, J. R., Mellouli, S., Nahon, K., Pardo, T. A. \& Scholl, H. J. (2012). Understanding smart cities: An integrative framework. 45th Hawaii international conference on system science, 2289-2297.

Colding, J., \& Barthel, S. (2017). An urban ecology critique on the "Smart City" model. Journal of Cleaner Production, 164, 95-101.

Cruz-Jesus, F., Oliveira, T., Bacao, F., \& Irani, Z. (2017). Assessing the pattern between economic and digital development of countries. Information Systems Frontiers, 19(4), 835-854.

Datta, A. (2016). Three big challenges for smart cities and how to solve them. The conversation. Available at: http://theconversation.com/ three-big-challenges-for-smart-cities-and-how-to-solve-them-59191 (Last accessed: December 15, 2017).

Djahel, S., Salehie, M., Tal, I. and Jamshidi, P. (2013). Adaptive traffic management for secure and efficient emergency services in smart cities. 2013 IEEE international conference on pervasive computing and communications workshops, 340-343.

Dubois, D., \& Prade, H. (1979). Operations in a fuzzy-valued logic. Information and Control, 43(2), 224-240.

Dwivedi YK, Wade MR \& Schneberger SL (2011a). Information Systems Theory: Explaining and Predicting Our Digital Society, pp 501, Springer science+business media, USA. Vol 1: https://doi.org/10. 1007/978-1-4419-6108-2.

Dwivedi YK, Wade MR \& Schneberger SL (2011b). Information Systems Theory: Explaining and Predicting Our Digital Society, pp 445, Springer Science+Business Media, Vol 2: https://doi.org/10.1007/ 978-1-4419-9707-4.

Dwivedi, Y. K., Kapoor, K. K., Williams, M. D., \& Williams, J. (2013). RFID systems in libraries: An empirical examination of factors affecting system use and user satisfaction. International Journal of Information Management, 33(2), 367-377.

Dwivedi, Y. K., Wastell, D., Laumer, S., Henriksen, H. Z., Myers, M. D., Bunker, D., et al. (2015). Research on information systems failures and successes: Status update and future directions. Information Systems Frontiers, 17(1), 143-157.

Dwivedi, Y. K., Shareef, M. A., Simintiras, A. C., Lal, B., \& Weerakkody, V. (2016). A generalised adoption model for services: A crosscountry comparison of mobile health (m-health). Government Information Quarterly, 33(1), 174-187.

Dwivedi, Y. K., Janssen, M., Slade, E., Rana, N. P., Weerakkody, V., Millard, J., Hidders, A. J. H., \& Snijder, D. (2017a). Driving innovation through big open linked data (BOLD): Exploring antecedents using interpretive structural modelling. Information Systems Frontiers, 19(2), 197-212.

Dwivedi, Y. K., Rana, N. P., Janssen, M., Lal, B., Williams, M. D., \& Clement, M. (2017b). An empirical validation of a unified model of electronic government adoption (UMEGA). Government Information Quarterly, 34(2), 211-230.

Dwivedi, Y. K., Rana, N. P., Jeyaraj, A., Clement, M., \& Williams, M. D. (2017c). Re-examining the unified theory of acceptance and use of technology (UTAUT): Towards a revised theoretical model. Information Systems Frontiers, 1-16. https://doi.org/10.1007/ s10796-017-9774-y.

Elmaghraby, A. S., \& Losavio, M. M. (2014). Cyber security challenges in smart cities: Safety, security and privacy. Journal of Advanced Research, 5(4), 491-497.

Elmangoush, A., Coskun, H., Wahle, S. and Magedanz, T. (2013). Design aspects for a reference M2M communication platform for smart cities. 9th international conference on innovations in information technology, 204-209.

Fast Company (2013). The 8 smartest cities in Latin America. Online available at: https://www.fastcompany.com/3022533/the-8 smartest-cities-in-latin-america. (Last accessed: July 26, 2018).

Ferrara, R. (2015). The smart city and the green economy in Europe: A critical approach. Energies, 8(6), 4724- 4734.

Glaeser, E. L., Resseger, M., \& Tobio, K. (2009). Inequality in cities. Journal of Regional Science, 49(4), 617-646.

Gluhak, A. (2017). Seven challenges for scaling IoT enabled smart cities. IoT UK, Available at: https://iotuk.org.uk/seven-challenges-forscaling-iot-enabled-smart-cities/ (Last accessed: December 16, 2017).

Govindan, K., Diabat, A., \& Shankar, K. M. (2015). Analyzing the drivers of green manufacturing with fuzzy approach. Journal of Cleaner Production, 96, 182-193.

Govindan, K., Mangla, S. K., \& Luthra, S. (2017). Prioritising indicators in improving supply chain performance using fuzzy AHP: Insights from the case example of four Indian manufacturing companies. Production Planning \& Control, 28(6-8), 552-573.

Guy, S., Medd, W., Marvin, S., \& Moss, T. (Eds.). (2011). Urban transitions: Intermediaries and the governance of socio-technical networks. London: Earth Scan.

Harputlugil, T., Prins, M., Gultekin, T. and Topcu, I. (2011). Conceptual framework for potential implementations of multi criteria decision making (MCDM) methods for design quality assessment. In Management and Innovation for a Sustainable Built Environment, Amsterdam, The Netherlands, June 20-23, ISBN: 9789052693958.

Hernández-Muñoz, J. M., Vercher, J. B., Muñoz, L., Galache, J. A., Presser, M., Gómez, L. A. H. and Pettersson, J. (2011). Smart cities at the forefront of the future internet. In The future internet assembly, 447-462. Springer, Berlin, Heidelberg.

Hossain, M. A., \& Dwivedi, Y. K. (2014). What improves citizens' privacy perceptions toward RFID technology? A cross-country investigation using mixed method approach. International Journal of Information Management, 34(6), 711-719.

Hughes, D. L., Dwivedi, Y. K., Rana, N. P., \& Simintiras, A. C. (2016). Information systems project failure - Analysis of causal links using interpretive structural modelling. Production Planning \& Control, 27(16), 1313-1333. 
Hughes, D. L., Dwivedi, Y. K., \& Rana, N. P. (2017). Mapping IS failure factors on PRINCE2 ${ }^{\circledR}$ stages: An application of interpretive ranking process (IRP). Production Planning \& Control, 28(9), 776-790.

IET (2017). Smart cities - Time to involve the people. The Institution of Engineering and Technology. Available at: http://www.theiet.org/ sectors/thought-leadership/future-cities/articles/smart-citiesinvolve. $\mathrm{cfm}$ ?utm_source=redirect\&utm_medium =any\&utmcampaign $=$ smartcities (Last accessed: December 16, 2017).

Ishizaka, A., \& Labib, A. (2009). Analytic hierarchy process and expert choice: Benefits and limitations. OR Insight, 22(4), 201-220.

Janssen, M., Konopnicki, D., Snowdon, J. L., \& Ojo, A. (2017). Driving public sector innovation using big and open linked data (BOLD). Information Systems Frontiers, 19(2), 189-195.

Janssen, M., Rana, N. P., Slade, E., \& Dwivedi, Y. K. (2018). Trustworthiness of digital government services: Deriving a comprehensive theory through interpretive structural modelling. Public Management Review, 20(5), 647-671.

Junior, F. R. L., Osiro, L., \& Carpinetti, L. C. R. (2014). A comparison between fuzzy AHP and fuzzy TOPSIS methods to supplier selection. Applied Soft Computing, 21, 194-209.

Kandpal, V., Kaur, H. and Tyagi, V. (2017). Smart city projects in India: Issues and challenges.

Kapoor, K. K., Dwivedi, Y. K., \& Williams, M. D. (2014a). Rogers' innovation adoption attributes: A systematic review and synthesis of existing research. Information Systems Management, 31(1), 74 91.

Kapoor, K. K., Dwivedi, Y. K., \& Williams, M. (2014b). Innovation adoption attributes: A review and synthesis of research findings. European Journal of Innovation Management, 17(3), 327-348.

Kapoor, K. K., Dwivedi, Y. K., \& Williams, M. D. (2015). Examining the role of three sets of innovation attributes for determining adoption of the interbank mobile payment service. Information Systems Frontiers, 17(5), 1039-1056.

Kar, A. K. (2015). A hybrid group decision support system for supplier selection using analytic hierarchy process, fuzzy set theory and neural network. Journal of Computational Science, 6, 23-33.

Khan, Z., Pervez, Z., \& Abbasi, A. G. (2017). Towards a secure service provisioning framework in a smart city environment. Future Generation Computer Systems, 77, 112-135.

Kitchin, R. (2015). The promise and peril of smart cities. Computers and Law: The Journal of the Society for Computers and Law, 26(2), 1-5.

Kogan, N. and Lee, K.J. (2014). Exploratory research on success factors and challenges of smart city projects. MSc Thesis, Kyung Hee University, Seoul, South Korea.

Komninos, N., Pallot, M., \& Schaffers, H. (2013). Special issue on smart cities and the future internet in Europe. Journal of the Knowledge Economy, 4(2), 119-134.

Koo, C., Ricci, F., Cobanoglu, C., \& Okumus, F. (2017). Special issue on smart, connected hospitality and tourism. Information Systems Frontiers, 19(4), 699-703.

Koppenjan, J. F., \& Enserink, B. (2009). Public-private partnerships in urban infrastructures: Reconciling private sector participation and sustainability. Public Administration Review, 69(2), 284-296.

Lazaroiu, G. C., \& Roscia, M. (2012). Definition methodology for the smart cities model. Energy, 47(1), 326-332.

Lee, J., \& Lee, H. (2014). Developing and validating a citizen-centric typology for smart city services. Government Information Quarterly, 31, S93-S105.

Lee, J. H., Phaal, R., \& Lee, S. H. (2013). An integrated service-devicetechnology roadmap for smart city development. Technological Forecasting and Social Change, 80(2), 286-306.

Lee, J. H., Hancock, M. G., \& Hu, M. C. (2014). Towards an effective framework for building smart cities: Lessons from Seoul and San Francisco. Technological Forecasting and Social Change, 89, 8099.
Letaifa, S. B. (2015). How to strategize smart cities: Revealing the SMART model. Journal of Business Research, 68(7), 1414-1419.

Li, S., Da Xu, L., \& Zhao, S. (2015). The internet of things: A survey. Information Systems Frontiers, 17(2), 243-259.

Lin, R. J. (2013). Using fuzzy DEMATEL to evaluate the green supply chain management practices. Journal of Cleaner Production, 40, 32-39.

Liu, J., Li, J., Li, W., \& Wu, J. (2016). Rethinking big data: A review on the data quality and usage issues. ISPRS Journal of Photogrammetry and Remote Sensing, 115, 134-142.

Luthra, S., Garg, D., \& Haleem, A. (2013). Identifying and ranking of strategies to implement green supply chain management in Indian manufacturing industry using analytical hierarchy process. Journal of Industrial Engineering and Management, 6(4), 930-962.

Luthra, S., Mangla, S. K., \& Kharb, R. K. (2015). Sustainable assessment in energy planning and management in Indian perspective. Renewable and Sustainable Energy Reviews, 47, 58-73.

Luthra, S., Govindan, K., Kharb, R. K., \& Mangla, S. K. (2016a). Evaluating the enablers in solar power developments in the current scenario using fuzzy DEMATEL: An Indian perspective. Renewable and Sustainable Energy Reviews, 63, 379-397.

Luthra, S., Mangla, S. K., Xu, L., \& Diabat, A. (2016b). Using AHP to evaluate barriers in adopting sustainable consumption and production initiatives in a supply chain. International Journal of Production Economics, 181, 342-349.

Mandal, T. (2016). Smart cities must be smart about emissions. India climate dialogue, accessed from http://indiaclimatedialogue.net/ $2016 / 02 / 26 /$ smart-cities-must-be-smart-about-emissions/ on $15^{\text {th }}$ December 2017.

Mangla, S. K., Kumar, P., \& Barua, M. K. (2015). Risk analysis in green supply chain using fuzzy AHP approach: A case study. Resources, Conservation and Recycling, 104, 375-390.

Mangla, S. K., Govindan, K., \& Luthra, S. (2016). Critical success factors for reverse logistics in Indian industries: A structural model. Journal of Cleaner Production, 129, 608-621.

Mangla, S. K., Govindan, K., \& Luthra, S. (2017). Prioritizing the barriers to achieve sustainable consumption and production trends in supply chains using fuzzy analytical hierarchy process. Journal of Cleaner Production, 151, 509-525.

Mckinsey Report (2018). Combating the challenges of urbanization in emerging markets: Lessons from India. Accessed from https://www. mckinsey.com/industries/capital-projects-and-infrastructure/ourinsights/combating-the-challenges-of-urbanization-in-emergingmarkets-lessons-from-india on 22th April 2018.

Mohanty, S. P., Choppali, U., \& Kougianos, E. (2016). Everything you wanted to know about smart cities: The internet of things is the backbone. IEEE Consumer Electronics Magazine, 5(3), 60-70.

Monzon, A. (2015). Smart cities concept and challenges: Bases for the assessment of smart city projects. International conference on smart cities and green ICT systems, 17-31.

Mori, K., \& Christodoulou, A. (2012). Review of sustainability indices and indicators: Towards a new City sustainability index (CSI). Environmental Impact Assessment Review, 32(1), 94-106.

Nair, S. (2017). The too smart city. Indian Express. Available at: http:// indianexpress.com/article/opinion/columns/smart-city-missionurban-development-4721785/ (Last accessed: August 20, 2017).

Nam, T. and Pardo, T. A. (2011). Conceptualizing smart city with dimensions of technology, people, and institutions. 12th Annual International Digital Government Research Conference: Digital Government Innovation in Challenging Times, 282-291.

Naphade, M., Banavar, G., Harrison, C., Paraszczak, J., \& Morris, R. (2011). Smarter cities and their innovation challenges. Computer, 44(6), 32-39.

Neirotti, P., De Marco, A., Cagliano, A. C., Mangano, G., \& Scorrano, F. (2014). Current trends in Smart City initiatives: Some stylised facts. Cities, 38, 25-36. 
OCED (2015). The path to happiness lies in good health and a good job, the better life index shows. The organisation for economic cooperation and development (OECD), Paris, France. Available at: http://www.oecd.org/newsroom/the-path-to-happiness-lies-in-goodhealth-and-a-good-job-the-better-life-index-shows.htm (Last accessed: January 24, 2018).

Ordoobadi, S. M. (2010). Application of AHP and Taguchi loss functions in supply chain. Industrial Management \& Data Systems, 110(8), $1251-1269$.

Paskaleva, K. A. (2011). The smart city: A nexus for open innovation? Intelligent Buildings International, 3(3), 153-171.

Pereira, G. V., Macadar, M. A., Luciano, E. M., \& Testa, M. G. (2017). Delivering public value through open government data initiatives in a Smart City context. Information Systems Frontiers, 19(2), 213229.

Perera, C., Zaslavsky, A., Christen, P., \& Georgakopoulos, D. (2014). Sensing as a service model for smart cities supported by internet of things. Transactions on Emerging Telecommunications Technologies, 25(1), 81-93.

Petrolo, R., Loscri, V., \& Mitton, N. (2017). Towards a smart city based on cloud of things, a survey on the smart city vision and paradigms. Transactions on Emerging Telecommunications Technologies, 28(1), 29-31.

Platts, K. W., \& Gregory, M. J. (1990). Manufacturing audit in the process of strategy formulation. International Journal of Operations \& Production Management, 10(9), 5-26.

Prakash, C., \& Barua, M. K. (2015). Integration of AHP-TOPSIS method for prioritizing the solutions of reverse logistics adoption to overcome its barriers under fuzzy environment. Journal of Manufacturing Systems, 37, 599-615.

Rana, N. P., \& Dwivedi, Y. K. (2015). Citizen's adoption of an egovernment system: Validating extended social cognitive theory (SCT). Government Information Quarterly, 32(2), 172-181.

Rana, N. P., Dwivedi, Y. K., \& Williams, M. D. (2015a). A meta-analysis of existing research on citizen adoption of e-government. Information Systems Frontiers, 17(3), 547-563.

Rana, N. P., Dwivedi, Y. K., Williams, M. D., \& Weerakkody, V. (2015b). Investigating success of an e-government initiative: Validation of an integrated IS success model. Information Systems Frontiers, 17(1), $127-142$.

Rana, N. P., Dwivedi, Y. K., Williams, M. D., \& Weerakkody, V. (2016). Adoption of online public grievance redressal system in India: Toward developing a unified view. Computers in Human Behavior, 59, 265-282.

Rana, N. P., Dwivedi, Y. K., Lal, B., Williams, M. D., \& Clement, M. (2017). Citizens' adoption of an electronic government system: Towards a unified view. Information Systems Frontiers, 19(3), 549-568.

Rathore, M. M., Ahmad, A., Paul, A., \& Rho, S. (2016). Urban planning and building smart cities based on the internet of things using big data analytics. Computer Networks, 101, 63-80.

Saaty, T. L. (1980). The analytic hierarchy process: Planning. Priority setting. Resource Allocation. MacGraw-Hill, New York International Book Company, 287.

Sadorsky, P. (2014). The effect of urbanization on CO2 emissions in emerging economies. Energy Economics, 41, 147-153.

Sahoo, S., Dhar, A., \& Kar, A. (2016). Environmental vulnerability assessment using Grey analytic hierarchy process based model. Environmental Impact Assessment Review, 56, 145-154.

Santana, E. F. Z., Chaves, A. P., Gerosa, M. A., Kon, F., \& Milojicic, D. S. (2017). Software platforms for smart cities: Concepts, requirements, challenges, and a unified reference architecture. ACM Computing Surveys, 50(6), 78.

Schuurman, D., Baccarne, B., De Marez, L., \& Mechant, P. (2012). Smart ideas for smart cities: Investigating crowdsourcing for generating and selecting ideas for ICT innovation in a city context. Journal of
Theoretical and Applied Electronic Commerce Research, 7(3), 4962.

Scuotto, V., Ferraris, A., \& Bresciani, S. (2016). Internet of things: Applications and challenges in smart cities: A case study of IBM smart city projects. Business Process Management Journal, 22(2), 357-367.

Shareef, M. A., Kumar, V., Kumar, U., \& Dwivedi, Y. K. (2011). Egovernment adoption model (GAM): Differing service maturity levels. Government Information Quarterly, 28(1), 17-35.

Shareef, M. A., Kumar, V., Dwivedi, Y. K., \& Kumar, U. (2016a). Service delivery through mobile-government (mGov): Driving factors and cultural impacts. Information Systems Frontiers, 18(2), 315-332.

Shareef, M. A., Dwivedi, Y. K., Kumar, V., \& Kumar, U. (2016b). Reformation of public service to meet citizens' needs as customers: Evaluating SMS as an alternative service delivery channel. Computers in Human Behavior, 61, 255-270.

Shareef, M. A., Dwivedi, Y. K., Kumar, V., \& Kumar, U. (2017). Content design of advertisement for consumer exposure: Mobile marketing through short messaging service. International Journal of Information Management, 37(4), 257-268.

Sinha, A., Kumar, P., Rana, N. P., Islam, R., \& Dwivedi, Y. K. (2017). Impact of internet of things (IoT) in disaster management: A tasktechnology fit perspective. Annals of Operations Research, 1-36. https://doi.org/10.1007/s10479-017-2658-1.

Slade, E. L., Dwivedi, Y. K., Piercy, N. C., \& Williams, M. D. (2015). Modeling consumers' adoption intentions of remote mobile payments in the United Kingdom: Extending UTAUT with innovativeness, risk, and trust. Psychology \& Marketing, 32(8), 860-873.

Solanas, A., Patsakis, C., Conti, M., Vlachos, I. S., Ramos, V., Falcone, F., Postolache, O., Martinez-Balleste, P. A., Pietro, R. D., Perrea, D. N., \& Martinez-Balleste, A. (2014). Smart health: A context-aware health paradigm within smart cities. IEEE Communications Magazine, 52(8), 74-81.

Tachizawa, E. M., Alvarez-Gil, M. J., \& Montes-Sancho, M. J. (2015). How "smart cities" will change supply chain management. Supply Chain Management: An International Journal, 20(3), 237-248.

The Indian Express (2016). Quality of life: Which is the best Indian city to live in? Available at:http://indianexpress.com/article/india/indianews-india/where-to-live-in-india-which- city-offers-the-bestquality-of-living-2891060/ (Last accessed: January 24, 2018).

UNFPA (2008). State of World population 2007: Unleashing the potential of urban growth. United Nations Population Fund (UNFPA), New York, 2008.

van Zoonen, L. (2016). Privacy concerns in smart cities. Government Information Quarterly, 33(3), 472-480.

Veeramootoo, N., Nunkoo, R., \& Dwivedi, Y. K. (2018). What determines success of an e-government service? Validation of an integrative model of e-filing continuance usage. Government Information Quarterly, https://doi.org/10.1016/j.giq.2018.03.004, 35, 161, 174.

Voss, C., Tsikriktsis, N., \& Frohlich, M. (2002). Case research in operations management. International Journal of Operations \& Production Management, 22(2), 195-219.

Washburn, D., Sindhu, U., Balaouras, S., Dines, R. A., Hayes, N. M., \& Nelson, L. E. (2010). Helping CIOs understand "Smart City" initiatives: Defining the smart city, its drivers, and the role of the CIO. Cambridge: Forrester Research.

Weber, R. H. (2013). Internet of things-governance quo vadis? Computer Law \& Security Review, 29(4), 341-347.

Weber, R. H., \& Studer, E. (2016). Cyber security in the internet of things: Legal aspects. Computer Law \& Security Review, 32(5), 715-728.

Weerakkody, V., El-Haddadeh, R., Al-Sobhi, F., Shareef, M. A., \& Dwivedi, Y. K. (2013). Examining the influence of intermediaries in facilitating e-government adoption: An empirical investigation. International Journal of Information Management, 33(5), 716-725.

Weerakkody, V., Irani, Z., Kapoor, K., Sivarajah, U., \& Dwivedi, Y. K. (2017). Open data and its usability: An empirical view from the 
Citizen's perspective. Information Systems Frontiers, 19(2), 285300 .

Weisi, F. U., \& Ping, P. E. N. G. (2014). A discussion on smart city management based on meta-synthesis method. Management Science and Engineering, 8(1), 68-72.

Whitmore, A., Agarwal, A., \& Da Xu, L. (2015). The internet of thingsA survey of topics and trends. Information Systems Frontiers, 17(2), 261-274.

Yang, K., \& Callahan, K. (2007). Citizen involvement efforts and bureaucratic responsiveness: Participatory values, stakeholder pressures, and administrative practicality. Public Administration Review, 67(2), 249-264.

Yigitcanlar, T. (2015). Smart cities: An effective urban development and management model? Australian Planner, 52(1), 27-34.

Yoon, A. (2015). How smart cities enable urban sustainability. Online available at: https://www.triplepundit.com/2015/08/smart-citiesenable-urban-sustainability/ (Last accessed: December 15, 2017).

Zadeh, L. A. (1965). Information and control. Fuzzy Sets, 8(3), 338-353.

Zanella, A., Bui, N., Castellani, A., Vangelista, L., \& Zorzi, M. (2014). Internet of things for smart cities. IEEE Internet of Things journal, l(1), 22-32.

Zhang, K., Ni, J., Yang, K., Liang, X., Ren, J., \& Shen, X. S. (2017). Security and privacy in smart city applications: Challenges and solutions. IEEE Communications Magazine, 55(1), 122-129.

Zygiaris, S. (2013). Smart city reference model: Assisting planners to conceptualize the building of smart city innovation ecosystems. Journal of the Knowledge Economy, 4(2), 217-231.

Nripendra P Rana is an Associate Professor and the Director of Postgraduate Research at the School of Management of Swansea University, UK. His current research interests focus primarily upon adoption of emerging and cutting edge technology in general and e-government, m-government, e-commerce and m-commerce systems in particular. His work has been published in leading academic journals such as European Journal of Marketing, Information Systems Frontiers, Government Information Quarterly and Computers in Human Behavior. $\mathrm{He}$ is an Associate Editor of International Journal of Information Management and Global Journal of Flexible Systems Management.

Sunil Luthra is working in the State Institute of Engineering and Technology (formerly known as Government Engineering College), Nilokheri, Haryana, India. He completed his $\mathrm{PhD}$ from the National Institute of Technology, Kurukshetra. He has been associated with teaching for the last 16 years. He has contributed over 100 research papers in international referred and national journals, and conferences at international and national level. He showed his research aptitude by publishing several research papers in high impact factors international journals. He has an excellent research track record (more than 164 research impact points; received more than 1,700 citations on Google Scholar; H-index 21 on Google Scholar; research gate score is $87.5 \%$ above of registered research gate members). His research interests includes production and operations management, green/sustainable/circular supply chain management, energy sustainability, renewable/sustainable energies, sustainable consumption and production, reverse logistics and technology and innovation management etc.
Sachin Kumar Mangla is a lecturer of Knowledge Management and Business Decision-making, in Plymouth Business School, University of Plymouth, Plymouth, United Kingdom. He is working in the field of Green Supply Chain; Sustainability; Decision-Making; Smart Manufacturing; Machine Learning; Risk Management; Simulation; optimisation; Reverse Logistics; Renewable Energy; Empirical research. He did his doctorate (specialisation Operations and Supply Chain Management) from Indian Institute of Technology (IIT), Roorkee. He loves to write research papers and projects. He has published/presented several papers in repute (ABS and ABDC indexed) international/national journals. He has an h-index 16, i10-index 20 and Google Scholar Citations of more than 800. He has received 2017 Most Cited Paper Award for his paper entitled "Risk analysis in green chain using fuzzy AHP approach: a case study". Currently, he is editing a book "Sustainable Procurement in Supply Chain Operations" published under CRC Press (Taylor \& Francis Group).

Rubina Islam is a Ph.D. Student at University of Salford business school. Rubina has a background in IT and accounting. Rubina is also an expert in a range of quantitative methods and has extensively engaged with researchers globally. Rubina is working at analysing outsourcing as part of her doctoral research and has published and presented her work at conferences and journals.

Sian Roderick is a Lecturer at the School of Management, Swansea University, UK. Her current teaching and research interests focus primarily upon innovation adoption. She currently teaches modules related to Innovation Management, Research Methods, and Enterprise, Innovation and Intellectual Property.

Yogesh K. Dwivedi is a Professor of Digital Marketing and Innovation, Dean of Academic Leadership (REF Research Environment and REF Interdisciplinary Research), and Director of the Emerging Markets Research Centre (EMaRC) in the School of Management at Swansea University, Wales, UK. His research interests are at the interface of Information Systems (IS) and Marketing, focusing on issues related to consumer adoption and diffusion of emerging ICT-based applications, electronic/digital government, and digital marketing particularly in the context of emerging markets. He has published more than 250 articles in a range of leading academic journals and conferences. He has coedited/co-authored more than 20 books on technology adoption, e-government, IS theory, eWOM and social media which have been published by international publishers such as Chandos Publishing (an imprint of Elsevier), Springer, Chapman and Hall/CRC Press, Routledge and Emerald. He has acted as co-editor of 19 journal special issues; organised tracks, mini-tracks and panels in leading conferences; and served as Programme Co-Chair of the 2013 IFIP WG 8.6 Conference on Grand Successes and Failures in IT: Public and Private Sectors and as Conference Chair of the IFIP WG 6.11 I3E2016 Conference on Social Media: The Good, the Bad, and the Ugly. He is an Editor in Chief of International Journal of Information Management, an Associate Editor of the European Journal of Marketing and Government Information Quarterly, and Senior Editor of the Journal of Electronic Commerce Research. Professor Dwivedi is the founding editor of the recently established Springer Book Series on Advances in Theory and Practice of Emerging Markets (http://www.springer.com/series/15802). More information about Professor Dwivedi can be found at: http://www. swansea.ac.uk/staff/som/academic-staff/y.k.dwivedi/. 